\title{
A New FDI Potential Index: Design and Application to the EU Regions
}

\author{
ADOLFO MAZA* \& JOSÉ VILLAVERDE**** \\ ${ }^{*}$ Department of Economics, University of Cantabria, Santander, Spain, ${ }^{* *}$ Kemmy Business School, \\ University of Limerick, Limerick, Ireland
}

(Received July 2014; accepted February 2015)

\begin{abstract}
The aim of this paper is to propose a new way of computing the FDI Potential Index to address the issue of FDI attractiveness at the EU regional level. This new index employs a sound way of selecting the variables involved in its construction, for which a factor analysis is performed. Accordingly, six factors ("economic potential", "market size", "labour situation", "technological progress", "labour regulation" and "competitiveness") are identified. Next, by applying the methodology of composite indicators and considering different weighting and aggregation schemes, three versions (un-weighted linear, weighted linear and weighted geometric) of the new FDI Potential Index are computed. Afterwards, the comparison of the weighted linear version of the Potential Index with the conventional FDI Performance Index allows us to apply the United Nations Conference on Trade and Development (UNCTAD) FDI typology. The results reveal considerable heterogeneity among EU regions in terms of FDI attractiveness, and that regions belonging to the same group of the UNCTAD classification are highly concentrated from a geographical perspective. In view of these findings, we compute an additional version of both the FDI Potential and Performance indices, in which the geographical location of each region plays a key role. Based on these spatial indices, some general policy implications are drawn.
\end{abstract}

Keywords: FDI Potential Index; FDI Performance Index; UNCTAD FDI typology; factor analysis; European regions

\section{Introduction}

The interest in FDI, and consequently the literature on it, has widely increased in the last few decades, mainly because of the general recognition of its key role as a growth engine. Among the many issues analysed by this literature, the study of FDI determinants from the point of view of the hosting economy (inward FDI) ${ }^{1}$ has received much attention (see Blonigen, 2005; Faeth, 2009 for surveys on this topic), as they are crucial to compare

Correspondence Address: Adolfo Maza, Department of Economics, University of Cantabria, Av. Los Castros, s/n, 39005 Santander, Spain. Email: mazaaj@unican.es 


\section{A. Maza \& J. Villaverde}

the "theoretical" FDI attractiveness of an economy to its actual performance. Drawing from this branch of the literature, there have been several attempts to benchmark FDI by means of various indicators, among which those proposed by UNCTAD (2002) - the FDI Performance and FDI Potential indices-clearly stand out.

As is well known, the United Nations Conference on Trade and Development (UNCTAD) FDI Performance Index states what actually happens with FDI and, as such, is widely used and accepted in empirical studies. However, the use and acceptance of the UNCTAD FDI Potential Index built to rank economies according to their potential capacity to attract FDI is somewhat more restricted; actually, even UNCTAD itself seems to show a hint of dissatisfaction with the index as, for instance, it has changed quite often the set of variables involved in its construction.

This being so, it is also convenient to recall that there are at least two other interesting approaches to calibrate the FDI attractiveness of an economy, although neither of them have shown to be clearly superior to the UNCTAD approach. The first approach is the FDI Potential Index proposed by Kandogan (2012). Its construction is based on multiple cross-sectional estimations and the coefficients obtained by them for each variable. The second approach is that followed by the A.T. Kearney FDI Confidence Index, which adopts a micro perspective and is built as a weighted average of the responses obtained in a survey of senior executives of the world's leading corporations. Although appealing, we believe these two approaches have some drawbacks. Regarding the first, the sensitivity of the results to the presence of multicollinearity between the variables included, as well as possible specification errors leading to low goodness-of-fit values in the regressions, are the most important. Regarding the second, we believe that the main shortcoming lies in the fact that it only takes into account the specific expectations of the leaders of top companies.

Bearing all these considerations in mind, it is obvious that assessing FDI attractiveness is not an easy task. In this vein, UNCTAD states that "it is not possible, with the available data, to capture the host of factors that can affect FDI" (UNCTAD, 2002, p. 23). We believe, however, that there is some room for improvement of the UNCTAD FDI Potential Index and this is, in fact, the main purpose of this paper: to design a somewhat new and hopefully more accurate method of computing the FDI Potential Index. Our proposal, for which we use EU regions as a case study, is based on the UNCTAD approach but tries to improve it in three respects. Taking into account the large number of economic ${ }^{2}$ variables that both theoretical and empirical analysis highlight as main FDI determinants, and paying attention to regional data availability in the EU, we first select a larger set of potential FDI drivers (21 in this case) and employ factor analysis to reduce them to a manageable set of uncorrelated factors. Next, we apply a composite indicators approach to properly weight the extracted factors and use various aggregation schemes to compute the new FDI Potential Index. ${ }^{3}$ Afterwards, and because of the results so obtained, the findings of some previous works (e.g. Villaverde \& Maza, 2012), and the clear evidence that each region mainly competes with nearby regions, the paper also differs from the UNCTAD approach by explicitly paying attention to the geographical location of each region; this is done by computing what we call the "Spatial-Relative FDI Potential Index".

Furthermore, it is also important to point out that both in the aspatial and spatial cases, we compare the FDI Potential and Performance indices in order to gain some additional insights. This is done by applying the well-known UNCTAD FDI typology, which distinguishes among "front-runners", "above potential", "below-potential" and "under-performers". 
Finally, the paper also contributes to the growing literature on FDI by adopting, as mentioned, a regional approach. Although most papers provide a national perspective, it is obvious that this approach masks some important facts related to the different size and number of regions each country comprises. In addition, FDI flows play an important role not only in national but also in regional economic development (see, e.g. Markusen \& Venables, 1999). This is very relevant to the point that there is a strong competition among regions for attracting FDI (Phelps \& Raines, 2003). A clear example is the EU, as it is perceived to be a rather well-integrated area, so that country boundaries do not matter too much for the FDI location choice (Basile et al., 2009). Consequently, the analysis at the regional level is quite relevant from a politically oriented point of view, as regional governments have an important responsibility in attracting FDI (Fallon \& Cook, 2010).

The rest of the paper is organized as follows. The next section offers a brief survey of FDI theoretical and empirical (for the EU case) determinants. In Section 3, the data used throughout the paper are portrayed. In Section 4, and as a backdrop for the computation of our proposed FDI Potential Index, we review the UNCTAD FDI Potential Index and compute an adapted version of it for our sample of regions. Section 5 deals with the calculation of the new FDI Potential Index, for which, as mentioned before, a factor analysis and a composite indicators approach are carried out; to be precise, and by using various weighing and aggregation schemes, we compute three versions (un-weighted linear average, ${ }^{4}$ weighted linear average and weighted geometric average) of the new index. Section 6 combines the conventional Performance Index and the weighted linear average version of the new Potential Index to classify EU regions according to the UNCTAD FDI typology. After stressing that for any region it is important not only to know its general situation but also its situation relative to that of its main competitors (its closest neighbours), Section 7 recalculates both FDI Potential and Performance indices, by explicitly considering the role played by space; on the basis of the findings so obtained, some general policy implications are drawn. Section 8 concludes.

\section{FDI Determinants: A Literature Review}

Although the potential determinants of FDI have been studied extensively since the early sixties, giving rise to a large number of theories and models, ${ }^{5}$ none of them has been generally accepted yet. Apart from the models by Hymer (1960), based on industrial and organizational economics, and Vernon (1966), rooted in the product cycle hypothesis, there are basically three general explanations of muntinational enterprises (MNEs) activities: the so-called internalization theory (Buckley \& Casson, 1976), the OLI/eclectic paradigm and the macroeconomic approach (Kojima, 1973; Kojima \& Ozawa, 1984). Of these approaches, the OLI/eclectic paradigm ${ }^{6}$ - initially developed by Dunning $(1977,1979)$, and later refined due to the fact that firm-specific assets became increasingly mobile across natural boundaries and because of other changes in the organization and external environment of MNEs (Dunning, 2009) - is probably the most accepted one. This is so because this paradigm, being at the intersection of macro and micro approaches to MNEs, is able, to a certain extent, to summarize most of the FDI theories. ${ }^{7}$ Therefore, we use the OLI/eclectic paradigm as the basic framework for this paper. According to it, FDI can be explained "by identifying three types of special advantages that multinational enterprises (MNEs) have: ownership (O), location (L) and internalization (I) advantages" (Faeth, 2009, p. 171). Although, as pointed by Dunning (2000, p. 164) "the precise 
Table 1. Host country/region determinants of FDI

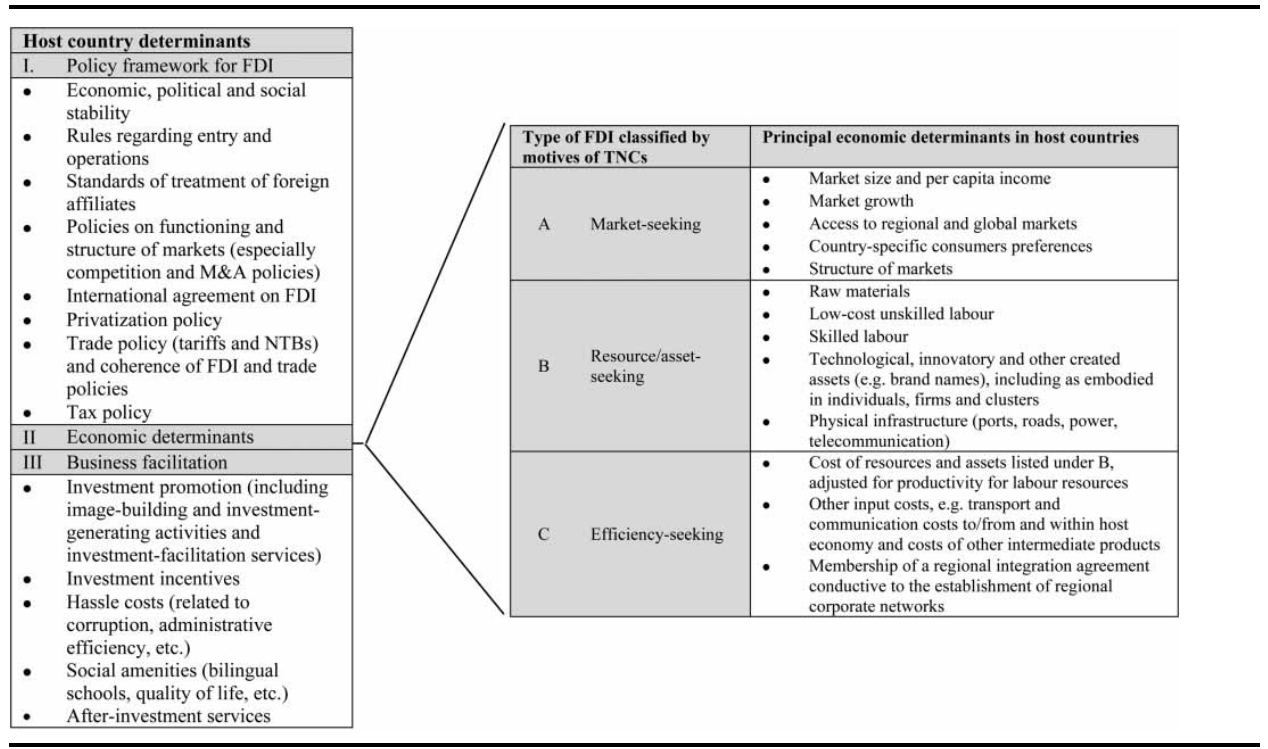

configuration of the OLI parameters facing any particular firm, and the response of the firm to that configuration, is strongly contextual", in this paper we focus just on the advantages of location, as the ownership and internalization advantages are firm-specific and considered as exogenous variables from the perspective of the host regions.

Table 1, taken from UNCTAD (2002), offers what it is arguably one of the best synthesis of the location advantages. This kind of advantage is usually divided into three groups: economic, political and sociocultural advantages. Political and sociocultural information is relatively scarce at the country level (UNCTAD, 2002), and even scarcer at the regional level. Therefore, here we put the emphasis on the economic advantages, which, closely related to the contextual variable of the raison d'etre for the FDI or type of investment, can be broken down into "resource/asset-seeking", "market-seeking" and "efficiency-seeking" determinants (Table 1). Although it is interesting to differentiate these three motives for FDI both from a theoretical and empirical perspective, it must be said that the links among them are quite often very strong and complex and that, as it also happens with the three advantages, they are more of a dynamic than static nature. Market-seeking investments (designed to satisfy foreign markets and most of which take the form of horizontal FDI) are obviously related to the market size of the host economies, while efficiency-seeking FDIs are motivated both to increase cost efficiency and rationalize the operation of MNEs based on resource-seeking and/or market-seeking investments.

Resource/asset-seeking is typically the most well-known group of FDI motivations, and is closely related to MNEs moving part of their production chain abroad (what it is usually called vertical FDI). According to this, MNEs decide their location considering the extant differences among the territories in terms of their resource endowments, something which is also obviously linked to efficiency seeking in that both are driven by differences in unit costs between locations. That is to say, MNEs are looking for securing natural resources (such as raw materials and low-cost unskilled or semiskilled labour), or alternatively for technological 
assets and a pool of skilled labour (strategic asset-seeking FDI). ${ }^{8}$ A condition for this FDI to take place is the existence of relatively good physical infrastructures in the host region.

Although the literature on FDI in Europe is relatively meagre, the results obtained provide evidence that resource/asset-seeking factors play a crucial role as determinants of FDI. In this respect it is convenient to recall, for example, the works by Basile et al. $(2008,2009)$ and Villaverde and Maza (2015), stressing labour conditions and R\&D expenditures as determinants of FDI. Casi and Resmini (2010), meanwhile, emphasize the importance of human capital when it comes to investing abroad, a result that is reinforced by Capello et al. (2011). Chidlow et al. (2009) find that, for some Polish regions, the availability of resources (labour and raw materials especially) is the main factor behind FDI flows. In the same vein, but for the Italian case, Majocchi and Presutti (2009) highlight the role of entrepreneurial resources, while with respect to the Russian example, Castiglione et al. (2012) confirm that good transport connections are important to attract FDI.

Apart from looking for resources, MNEs may also aim at having better access to foreign markets of greater dimension and at exploiting the possibilities granted by them. Therefore, among the market-seeking determinants, market size clearly stands out. Other motivations for investing included in this group are related, for example, to the necessity of adapting goods to local-specific consumer preferences, or to the wish to sustain or safeguard existing regional markets (that is, to have a presence on a specific market in order to discourage potential competitors from occupying it). Additionally, the so-called export platform FDI (MNEs use the host territory as a platform to export to third ones) is also included in this category. As is obvious, the existence of highly developed communications and transport infrastructures is, once again, a conducive condition for MNEs to get involved in market-seeking FDI.

From an empirical point of view, several papers have stressed the importance of marketseeking determinants in the EU at a regional level. Basile et al. (2008, 2009), Chidlow et al. (2009), Fallon and Cook (2010) and Castiglione et al. (2012) conclude, for example, that market size plays an important role in attracting FDI. Similarly, Casi and Resmini (2010) disclose that variables such as market potential and GDP growth are key explanatory factors of FDI regional location.

Finally, efficiency-seeking determinants are mainly related to differences in unit costs. The efficiency-seeking FDI is driven by the idea of creating new sources of competitiveness. According to Dunning (1993, p. 60), MNEs "take advantage of differences in the availability and costs of traditional factor endowments in different countries" and/or "take advantage of the economies of scale and scope and of differences in consumer tastes and supply capabilities".

As in the other cases, empirical evidence tends to support theoretical conclusions. This is so, for instance, in the papers by Casi and Resmini (2010), for a sample of regions belonging to all EU countries, and Villaverde and Maza (2012), for the Spanish regions, as both highlight the importance of labour costs in the MNEs decision to invest abroad. There are, however, some doubts about the relevance of this factor, particularly voiced by Capello et al. (2011).

\section{Data}

Prior to the empirical analysis, in this section we provide information about the data used throughout the paper. First of all it is important to note that, as mentioned in the introduc- 
tion, this paper adopts a regional perspective. To be precise, our sample comprises $260 \mathrm{EU}$ regions for the period 2000-2006.

Concerning the definition of regions, here we use the NUTS2 definition from 2003. The acronym NUTS stands for "Nomenclature of Territorial Units for Statistics", and it is the standard classification established by Eurostat to reference the administrative sections of a country. Although we are well aware that this administrative delimitation of regions could mask some key aspects of the EU economic reality (Maza \& Villaverde, 2011), we have adopted it because of data availability.

Regarding our sample period, here we wish to stress that the reason it goes from 2000 to 2006 is that this is the period for which we have homogenous data of inward FDI at the EU regional level. In any case, we think that, although the economic crisis starting in 2008 has changed remarkably the intensity of FDI flows, it has not substantially altered the FDI attractiveness of the regions.

As for the variables used in the paper, there are different cases. First we compute, as our benchmark for the remaining indices, a standard version of the UNCTAD Potential Index by using just a small number of variables. Then, we calculate different versions of a new FDI Potential Index, for which we employ a larger set of variables. Finally, we use FDI flows data in order to compute the Performance Index and compare its results with those of the various FDI Potential indices.

\subsection{Variables Used for the Computation of the UNCTAD FDI Potential Index}

To compute the FDI Potential Index with UNCTAD methodology, and in order to avoid the correlation problem arising when the number of variables is high, we settle on six variables: per capita GDP, R\&D expenditures as percentage of GDP, exports plus imports as percentage of GDP, the percentage of employment in high technology sectors, and the inverse of both unemployment rate and unit labour costs. Direct information about all these variables is reported in Table 2; although in the table there is no direct information about the unit labour costs, this variable has been computed as the ratio between compensation per employee (W) and labour productivity (LP), which are both included in the table.

\subsection{Variables Used for the Computation of the New FDI Potential Index}

Bearing in mind the theoretical considerations on FDI determinants, the empirical literature on them regarding the EU regions (see e.g. Basile et al., 2008, 2009; Casi \& Resmini, 2010; Capello et al., 2011; Voinea \& Van Kranenburg, 2011; Villaverde \& Maza, 2012, 2015), and, once again, data availability, our initial data set consists of a total of 21 variables. Although these variables try to capture the actual factors behind FDI, it must be agreed that, as often happens in empirical analysis, some of them can just be considered as crude proxies of them. ${ }^{9}$ The definitions, acronyms, units of measurement, data source and available years for these variables are reported in Table 2. In any case, and for the sake of clarity, a more detailed description and/or interpretation is offered for some variables:

- Openness degree. It is computed as the sum of exports and imports over GDP. 
Table 2. Databank

\begin{tabular}{|c|c|c|c|c|}
\hline Code & Description & Units & Source & Years \\
\hline $\mathrm{OP}$ & Openness degree & $\%$ GDP & Polasek and Sellner & $2000-2006$ \\
\hline GDP & Gross added value & $\begin{array}{r}\text { Constant mio } \\
\text { euros } 2000\end{array}$ & $\begin{array}{l}\text { Cambridge } \\
\text { Econometrics }\end{array}$ & $2000-2006$ \\
\hline PO & Population & Thousands & $\begin{array}{l}\text { Cambridge } \\
\text { Econometrics }\end{array}$ & $2000-2006$ \\
\hline GDPpc & $\begin{array}{l}\text { Per capita gross added } \\
\text { value }\end{array}$ & $\begin{array}{l}\text { Constant euros } \\
2000\end{array}$ & $\begin{array}{l}\text { Cambridge } \\
\text { Econometrics }\end{array}$ & $2000-2006$ \\
\hline LP & Labour productivity & $\begin{array}{l}\text { Constant euros } \\
2000\end{array}$ & $\begin{array}{l}\text { Cambridge } \\
\text { Econometrics }\end{array}$ & $2000-2006$ \\
\hline MSHARE & Manufacturing share & $\%$ & $\begin{array}{l}\text { Cambridge } \\
\text { Econometrics }\end{array}$ & $2000-2006$ \\
\hline W & $\begin{array}{l}\text { Compensation per } \\
\text { employee }\end{array}$ & $\begin{array}{l}\text { Constant euros } \\
2000\end{array}$ & $\begin{array}{l}\text { Cambridge } \\
\text { Econometrics }\end{array}$ & $2000-2006$ \\
\hline URinv & $\begin{array}{l}\text { (Inverse of) } \\
\text { Unemployment rate }\end{array}$ & $\%$ & $\begin{array}{l}\text { Cambridge } \\
\text { Econometrics }\end{array}$ & $2000-2006$ \\
\hline LTURinv & $\begin{array}{l}\text { (Inverse of) Long-term } \\
\text { unemployment rate }\end{array}$ & $\%$ & Eurostat & Selected years \\
\hline ER & Employment rate & $\%$ & $\begin{array}{l}\text { Cambridge } \\
\text { Econometrics }\end{array}$ & $2000-2006$ \\
\hline AR & Activity rate & $\%$ & $\begin{array}{l}\text { Cambridge } \\
\text { Econometrics }\end{array}$ & $2000-2006$ \\
\hline INV & Investment & $\begin{array}{r}\text { Constant mio } \\
\text { euros } 2000\end{array}$ & $\begin{array}{l}\text { Cambridge } \\
\text { Econometrics }\end{array}$ & $2000-2006$ \\
\hline TWinv & $\begin{array}{l}\text { (inverse of) Tax wedge } \\
\text { on employment }\end{array}$ & $\%$ & Eurostat & $2000-2006$ \\
\hline$R \& D$ & R\&D expenditure & $\%$ GDP & Eurostat & Selected years \\
\hline R\&DP & R\&D personnel & $\begin{array}{l}\% \text { Active } \\
\text { population }\end{array}$ & Eurostat & Selected years \\
\hline HTC & $\begin{array}{l}\text { High technology } \\
\text { sectors }\end{array}$ & $\begin{array}{l}\% \text { Total } \\
\text { employment }\end{array}$ & Eurostat & Selected years \\
\hline $\mathrm{HC}$ & Human capital & $\begin{array}{l}\% \text { Students at } \\
\text { ISCED levels } \\
5-6\end{array}$ & Eurostat & Selected years \\
\hline MULA & $\begin{array}{l}\text { Air and multimodal } \\
\text { accessibility }\end{array}$ & $\begin{array}{l}\text { Synthetic index: } \\
\mathrm{EU}=100\end{array}$ & ESPON & $2001 ; 2006$ \\
\hline LLRinv & $\begin{array}{l}\text { (inverse of) Labour } \\
\text { law rigidity }\end{array}$ & $\begin{array}{l}\text { Synthetic index } \\
(0-100)\end{array}$ & World Bank & 2004 \\
\hline LMR & $\begin{array}{l}\text { Labour market } \\
\text { regulation }\end{array}$ & $\begin{array}{l}\text { Synthetic index } \\
\quad(0-10)\end{array}$ & Fraser Institute & 2000; 2005 \\
\hline MP & Market potential & $\begin{array}{l}\text { Constant mio } \\
\text { euros } 2000\end{array}$ & $\begin{array}{l}\text { Own elaboration based } \\
\text { on Cambridge } \\
\text { Econometrics }\end{array}$ & $2000-2006$ \\
\hline
\end{tabular}

- Air and multimodal accessibility. This is an index combining several modal accessibility indicators, such as road, air, inland waterways and rail. The higher the index, the higher the accessibility.

- (Inverse of) Labour law rigidity. An index computed as an average of indices for alternative employment contracts, cost of increasing working hours, firing workers and dismissal procedures. The lower the index, the higher the rigidity. 
- Labour market regulation. An index giving high marks to regions allowing market forces to freely set wages and establish the conditions of dismissal, circumvent excessive unemployment benefits and refrain from the use of conscription.

- Market potential. The market potential for region $i$ is calculated as $\mathrm{MP}_{i}=\sum_{i \neq j} w_{i j} * \mathrm{GDP}_{j}$, where $w_{i j}$ are the elements of the distance matrix $W$ between each pair of regions $(i, j)$. Here, we have used the square of the inverse of the standardized distance as a distance matrix (Anselin, 1980).

As can be seen, we have a large battery of variables that, although in some cases can be simultaneously included into more than one of the FDI drivers' groups, could be arranged, according to Table 1, as follows:

(1) The economic determinants include market-seeking determinants (openness degree, gross added value, population, per capita gross added value, manufacturing share and market potential), resource/asset-seeking determinants (unemployment rate, employment rate, activity rate, $R \& D$ expenditures and personnel, high technology sector, human capital and air and multimodal accessibility) and efficiency-seeking determinants (labour productivity and compensation per employee).

(2) Variables related to the policy framework for FDI include the tax wedge on employment, labour law rigidity and labour market regulation.

(3) The business facilitation determinants are made up of investment. ${ }^{10}$

At this point, we consider that two important remarks regarding data availability are in place. First, when data are completely unavailable for some NUTS2 regions over the whole sample period (always for less than $5 \%$ of the total of regions; otherwise, the variable is removed from the analysis), ${ }^{11}$ we proceed as follows:

(a) If NUTS1 data are available, they are assigned to the NUTS2 regions.

(b) If NUTS1 data are unavailable but country data are available, they are assigned to NUTS2 regions.

(c) If neither NUTS1 nor country data are available, the process proceeds in three stages. To begin with, regions with a similar per capita GDP are identified; subsequently, for these regions the corresponding "variable/GDP" average ratio is calculated; lastly, for the NUTS2 regions we have no data a value equal to the product of their GDP times the aforementioned ratio is assigned.

Second, and due to the fact that, even after having done this, it still happens that there is no information for some variables in some specific years, we decide to compute average values (for the existing years) for all variables. Therefore, throughout the paper we consider the period 2000-2006 as a whole. This decision is also supported by the fact that FDI volatility (flows change significantly between years) renders the analysis of annual data quite unrepresentative (see Villaverde \& Maza, 2015). Furthermore, this approach is in line with UNCTAD's procedure, which in order to somewhat overcome data problems "uses data for three-year periods rather than a single year" (UNCTAD, 2001, p. 23). 


\title{
3.3. FDI Data Used in the Computation of the Performance Index
}

Although an analysis at the regional level gives richer information than one at the national level, providing a good basis for planning, researchers usually face an important problem when analysing FDI attractiveness from a regional angle; this is, in fact, that of FDI data availability. To cope with this, there have been several attempts for the EU case, among which the well-known FDIRegio and Elios databases stand out. Although quite interesting, these databases suffer from a critical drawback; they only offer information about the number of foreign firms with affiliates in the EU regions but not about the actual amounts invested by these companies.

In this paper, though, a new regional FDI database is used (Polasek \& Sellner, 2010, 2011, 2013). This database, which has already been employed in some papers dealing specifically with FDI issues at the regional level (e.g. Villaverde \& Maza, 2015), applies the spatial Chow-Lin procedure to give information about the actual amount of inward FDI. This procedure

\begin{abstract}
uses the relationship between a dependent variable that is only measured at a more aggregate regional level (...) and independent variables that are measured at a more disaggregate regional level $(\ldots)$ to predict the dependent variable at the disaggregate regional level. (Polasek \& Sellner, 2011, p. 25)
\end{abstract}

As this database provides information about the amount of inward FDI stocks at a regional level in current million euros, we first transform data from nominal into real terms (considering 2000 as the base year) by using national deflators and, then, compute FDI flows as the difference between consecutive inward FDI stocks. Therefore, FDI flows in 2000 prices are considered for the computation of the FDI Performance Index.

\section{UNCTAD FDI Potential Index}

As an attempt to benchmark the FDI attractiveness of national economies, and drawing on its expertise on FDI determinants, UNCTAD constructed in 2002 its first FDI Potential Index in a very simple but appealing way. First, UNCTAD settled on eight variables: the rate of growth of GDP, per capita GDP, share of exports in GDP, telephone lines per 1000 inhabitants, commercial energy use per capita, share of R\&D expenditures in gross national income, share of tertiary studies in the population and country risk-as the main FDI drivers. Second, it obtained the normalized scores for each variable by using the expression:

$$
\text { Normalized score }=\left[\frac{V_{i}-V_{\min }}{V_{\max }-V_{\min }}\right] * 100,
$$

where $V_{i}$ refers to the score of the value considered for country $i$ and $V_{\min }$ and $V_{\max }$ refer, respectively, to the lowest and highest scores of this factor among the territories. Third, the un-weighted linear average of the normalized scores for each economy was calculated in order to obtain the corresponding FDI Potential Index.

The main advantage of this index is its simplicity and easy of computation. However, it must be said that, being perhaps a bit unsatisfied with the index, UNCTAD has tried to 


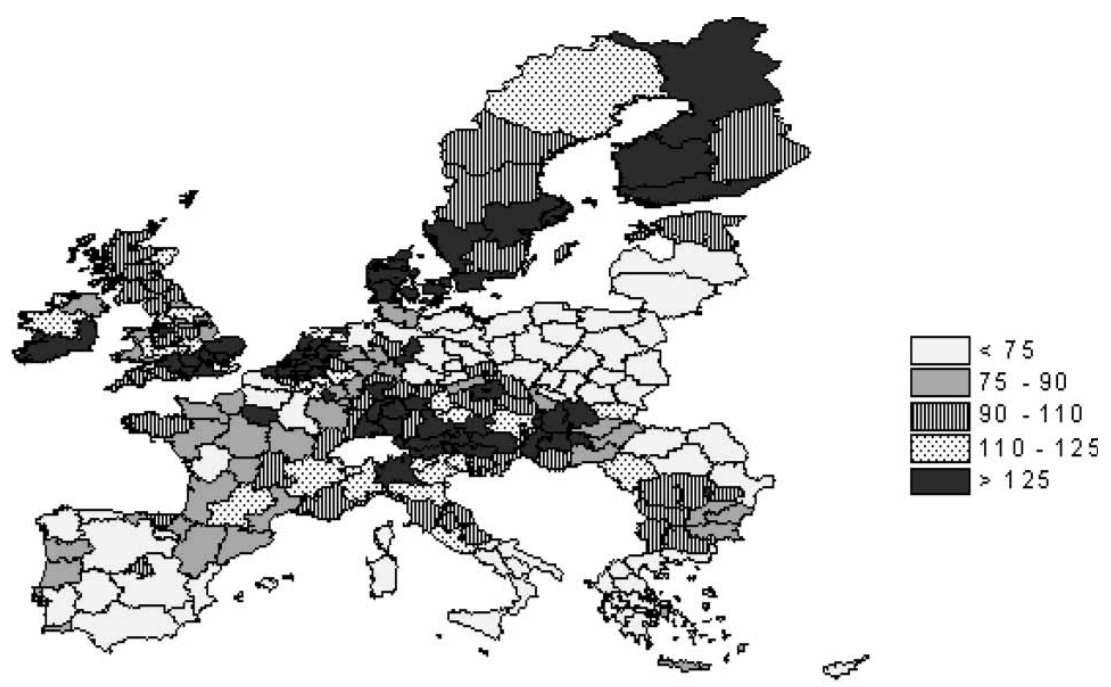

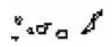

Figure 1. UNCTAD FDI Potential Index $(E U=100)$.

improve its reliability by either changing some of the variables included in its calculation and/or increasing their number (for a complete list of the variables considered in the last reports see e.g. UNCTAD, 2012). Nevertheless, so far UNCTAD has never proposed any methodological improvement.

In any case, as a starting point for our analysis and for the sake of comparison, we adapt the UNCTAD FDI Potential Index to our EU regional case. To be precise, we use average values (over the period 2000-2006) of the variables mentioned in the data section. Figure 1 displays the results obtained. As a whole, it can be observed that regions located in South and Eastern Europe seem to have the lowest potential to attract FDI, whereas those in Central and Northern Europe show the highest potential.

It is undoubted that this index deserves recognition as the first attempt to benchmark the FDI attractiveness of any location. However, the FDI Potential Index proposed by UNCTAD effectively suffers from some important drawbacks or disadvantages. These disadvantages are mainly related to the number and representativeness of the variables used in its construction, the likely high correlation between them (a problem that becomes the more severe the higher the number of variables considered), and the use of a simple but rather naive methodology to calculate the index. Since these problems somewhat reduce the reliability/accuracy of the index, we think a methodological improvement when it comes to assessing FDI attractiveness is welcome.

\section{A New FDI Potential Index: Design and Application to the EU Regions}

Our proposal differs from that of UNCTAD in three remarkable points, one regarding data and the remaining two concerning methodological issues. First, as indicated in Section 3 of 
the paper, it takes into consideration a larger number of the variables that theoretical and empirical studies have highlighted as key FDI drivers (see the surveys by Blonigen, 2005; Faeth, 2009). Second, it employs factor analysis in order to reduce the huge number of potential FDI drivers to a small and more manageable set of uncorrelated factors (see, e.g. Nardo et al., 2005). And third, it uses a sound approach to give weights to each factor and to aggregate them into a composite indicator.

\subsection{Methodological Issues}

Based on the databank previously mentioned, a crucial point in the construction of the new FDI Potential Index consists in performing a conventional factor analysis. This is basically made up of five steps:

First, it is necessary to normalise all variables, for which we employ the re-scaling method. Second, we compute the correlation between each pair of the original variables. As it happens that most of them have at least one correlation coefficient over 0.5 and the determinant of the correlation matrix is null (the results are available upon request), the conclusion is that applying factor analysis is appropriate.

The third step comprises the analyses of the correlation structure of the initial variables, for which conventional tests are employed. In particular, the Kaiser-Meyer-Olkin (KMO) measure of sampling adequacy (whether or not there are sufficient items for each factor) and Bartlett's test of sphericity (to check whether or not original variables are sufficiently correlated) were employed. The results show that the KMO statistic is greater than 0.5 (meaning that is significant), and Bartlett's measure on the correlation matrix passes at the 0.05 significance level. Therefore, our sample is adequate to conduct an exploratory factor analysis.

Subsequently, the fourth step involves applying the Kaiser's criterion for factor extraction. By doing so, six factors with eigenvalues greater than 1 are identified (Table 3), which explain $81.0 \%$ of the cumulative variance of the 21 original variables. The composition of these six factors is reported in Table 4. The first factor called "economic potential" and including labour productivity, per capita GDP, wages, air and multimodal accessibility, and market potential-explains more than $35.6 \%$ of the entire variance. The second factor, "market size", comprises GDP, population and investment variables. The third factor, "labour situation", includes the employment, activity, inverse of unemployment and inverse of long-term unemployment rates. The fourth factor, "technological progress", contains four indicators: R\&D investment, R\&D personnel, high technology sector and human capital. The fifth factor, "labour regulation", encompasses labour market regulation and the inverse of labour law rigidity and tax wedge. Finally, the sixth factor, "competitiveness", combines the openness degree (exports plus imports over GDP) and the manufacturing share.

Prior to moving forward in the analysis, it is worth mentioning that there is no doubt of the suitability of this sixth-factor solution because of three additional reasons (see Table 4). First of all, almost all original variables are highly correlated with just one factor and quite weakly with the others. Second, all variables have at least one factor loading greater (in absolute value) than 0.5 , which is regarded as being very significant. Finally, the reliability of the extracted factor structure is patent because it explains between $57.9 \%$ and $95.9 \%$ of the variance of each original variable; in fact, in 18 of the 21 cases it explains more than $70 \%$ of it. 
Table 3. Factor analysis. Total variance explained

\begin{tabular}{lccc}
\hline Factor & Eigenvalue & \% Variance & \% Cumulative variance \\
\hline $\mathbf{1}$ & $\mathbf{7 . 4 8 4}$ & $\mathbf{3 5 . 6 3 9}$ & $\mathbf{3 5 . 6 3 9}$ \\
$\mathbf{2}$ & $\mathbf{3 . 2 6 9}$ & $\mathbf{1 5 . 5 6 8}$ & $\mathbf{5 1 . 2 0 6}$ \\
$\mathbf{3}$ & $\mathbf{1 . 9 5 7}$ & $\mathbf{9 . 3 2 1}$ & $\mathbf{6 0 . 5 2 7}$ \\
$\mathbf{4}$ & $\mathbf{1 . 7 3 6}$ & $\mathbf{8 . 2 6 7}$ & $\mathbf{6 8 . 7 9 4}$ \\
$\mathbf{5}$ & $\mathbf{1 . 4 5 4}$ & $\mathbf{6 . 9 2 2}$ & $\mathbf{7 5 . 7 1 7}$ \\
$\mathbf{6}$ & $\mathbf{1 . 1 0 5}$ & $\mathbf{5 . 2 6 1}$ & $\mathbf{8 0 . 9 7 7}$ \\
7 & 0.799 & 3.806 & 84.784 \\
8 & 0.741 & 3.531 & 88.314 \\
9 & 0.546 & 2.601 & 90.915 \\
10 & 0.517 & 2.462 & 93.377 \\
11 & 0.352 & 1.678 & 95.054 \\
12 & 0.296 & 1.412 & 96.466 \\
13 & 0.260 & 1.236 & 97.702 \\
14 & 0.134 & 0.639 & 98.341 \\
15 & 0.115 & 0.550 & 98.891 \\
16 & 0.092 & 0.438 & 99.329 \\
17 & 0.063 & 0.300 & 99.629 \\
18 & 0.035 & 0.165 & 99.793 \\
19 & 0.017 & 0.080 & 99.874 \\
20 & 0.016 & 0.076 & 99.949 \\
21 & 0.011 & 0.051 & 100.000 \\
\hline
\end{tabular}

Note: Values in bold are factors with eigenvalue greater than 1.

The fifth step of the analysis entails that, once the (six) factors have been extracted and defined, it is necessary to create scores to represent the position of each region on each one of these factors. Although there are several approaches to compute these scores (DiStefano et al., 2009), we opt for the regression score approach. ${ }^{12}$

Having performed the factor analysis, the next move refers to the formal expression used to construct the new FDI Potential Index. Here, we first follow UNCTAD's approach; that is, we calculate an un-weighted linear average of the normalized factor scores. As we consider, however, that a simple un-weighted average is not the best way of proceeding, we then follow the suggestions of Nardo et al. (2005) for weighting and aggregation, and compute a weighted linear average; the weights are obtained as the normalized sum of the square factor loadings reported in Table 4. Finally, and for the sake of robustness, we also compute a weighted geometric average.

\subsection{Results}

As for the results, we first take a quick look at the factor scores, as we consider that the inclusion of a table would be too large and cumbersome to read (the results are available upon request). We think, however, that some comments trying to summarize the information (which regions are the best and worst placed in each factor) are in order: ${ }^{13}$

(1) From the point of view of the "economic potential", the situation of Belgian and French regions visibly stands out whereas those of mostly Romanian, Bulgarian and Polish regions get the lowest scores. 
Table 4. Factor analysis. Rotated component matrix

\begin{tabular}{|c|c|c|c|c|c|c|c|}
\hline Variable & Economic potential & Market size & Labour situation & Technological progress & Labour regulation & Competitiveness & Communalities \\
\hline $\mathrm{OP}$ & -0.042 & -0.207 & -0.093 & 0.051 & 0.068 & 0.817 & 0.729 \\
\hline GDP & 0.346 & 0.893 & 0.103 & 0.157 & -0.019 & -0.076 & 0.959 \\
\hline $\mathrm{PO}$ & -0.071 & 0.952 & -0.043 & 0.049 & -0.053 & -0.038 & 0.920 \\
\hline GDPpc & $\mathbf{0 . 8 3 5}$ & 0.136 & 0.348 & 0.253 & 0.033 & -0.124 & 0.917 \\
\hline LP & 0.931 & 0.116 & 0.149 & 0.183 & -0.025 & -0.105 & 0.947 \\
\hline MSHARE & -0.126 & 0.043 & 0.184 & -0.052 & -0.100 & 0.717 & 0.579 \\
\hline $\mathrm{W}$ & 0.929 & 0.120 & 0.168 & 0.189 & 0.008 & -0.054 & 0.944 \\
\hline Urinv & 0.393 & -0.106 & 0.667 & -0.048 & 0.338 & 0.085 & 0.734 \\
\hline LTURinv & 0.376 & -0.216 & 0.577 & -0.066 & 0.392 & -0.072 & 0.685 \\
\hline ER & 0.230 & 0.126 & 0.898 & 0.196 & 0.128 & 0.068 & 0.934 \\
\hline $\mathrm{AR}$ & 0.112 & 0.168 & 0.873 & 0.218 & 0.034 & 0.035 & 0.853 \\
\hline INV & 0.301 & 0.903 & 0.085 & 0.142 & -0.064 & -0.079 & 0.943 \\
\hline TWinv & -0.119 & -0.047 & 0.125 & -0.071 & 0.662 & -0.435 & 0.664 \\
\hline R\&D & 0.444 & 0.097 & 0.220 & 0.664 & -0.048 & 0.200 & 0.738 \\
\hline R\&DP & 0.342 & 0.102 & 0.200 & 0.855 & 0.004 & 0.018 & 0.898 \\
\hline HTC & 0.437 & 0.251 & 0.285 & 0.537 & 0.250 & 0.251 & 0.748 \\
\hline $\mathrm{HC}$ & -0.324 & 0.141 & -0.093 & 0.678 & -0.122 & -0.330 & 0.717 \\
\hline MULA & 0.599 & 0.347 & 0.216 & 0.314 & 0.024 & 0.306 & 0.719 \\
\hline LLRinv & 0.345 & -0.075 & 0.336 & 0.064 & 0.708 & 0.030 & 0.744 \\
\hline LMR & -0.030 & -0.009 & 0.065 & -0.020 & 0.939 & 0.113 & 0.901 \\
\hline MP & 0.805 & 0.143 & 0.142 & -0.123 & 0.158 & -0.044 & 0.731 \\
\hline
\end{tabular}

Note: Values in bold are factors in which each variable loads higher. 
(2) With respect to "market size", French regions are on the best position, while Greek and Austrian ones are on the opposite end.

(3) UK regions occupy forward positions regarding the "labour situation" factor; in contrast, regions belonging to Belgium, France and Italy are, among others, are backward.

(4) Nordic regions are prominent in relation to "technological progress". At the other end of the spectrum, it is quite a remarkably bad situation of some EU15 regions, most of them belonging to Spain, Greek and Italy.

(5) As for "labour regulation", the two polar positions are mainly occupied by some British (the best) and German (the worst) regions.

(6) Finally, "competiveness" is quite high in many of the EU15 regions but also in some Czech, Hungarian and Slovak ones. In contrast, the situation of Greek and some Spanish and Portuguese regions in this factor is quite deficient.

Now we focus our attention on the new FDI Potential Index. We have indeed computed the three versions previously mentioned. But it would be too repetitive and tedious to display the results for all of them, so it seems pertinent to pick out just one. As a criterion to do that, we calculate the correlation coefficients between, on the one hand, each one of these indices and, on the other, the percentage of FDI actually received by each region (measured both as the average of FDI flows for the sample period and as the FDI stock in year 2006). In addition, and trying to assess if the new indices are more reliable than the UNCTAD index computed in the previous section, we also include the latter in the calculations. As can be seen, the correlation coefficients are higher for the three new FDI Potential indices than for the UNCTAD one (Table 5). In our view, this is clear proof

Table 5. Correlation coefficients between FDI shares and different potential indices

\begin{tabular}{|c|c|c|c|c|c|}
\hline & $\begin{array}{l}\mathrm{FDI}_{i} l \\
\text { FDI }\end{array}$ & UNCTAD & $\begin{array}{l}\text { Un-weighted } \\
\text { linear average }\end{array}$ & $\begin{array}{l}\text { Weighted linear } \\
\text { average }\end{array}$ & $\begin{array}{l}\text { Weighted } \\
\text { geometric } \\
\text { average }\end{array}$ \\
\hline \multicolumn{6}{|c|}{ (a) Average FDI flows (2000-2006) } \\
\hline $\mathrm{FDI}_{i} / \mathrm{FDI}$ & 1.00 & & & & \\
\hline UNCTAD & 0.35 & 1.00 & & & \\
\hline $\begin{array}{l}\text { Un-weighted } \\
\text { linear average }\end{array}$ & 0.43 & 0.83 & 1.00 & & \\
\hline $\begin{array}{l}\text { Weighted linear } \\
\text { average }\end{array}$ & 0.45 & 0.68 & 0.84 & 1.00 & \\
\hline $\begin{array}{l}\text { Weighted } \\
\text { geometric } \\
\text { average }\end{array}$ & 0.45 & 0.57 & 0.77 & 0.89 & 1.00 \\
\hline \multicolumn{6}{|l|}{ (b) FDI stock (2006) } \\
\hline $\mathrm{FDI}_{i} / \mathrm{FDI}$ & 1.00 & & & & \\
\hline UNCTAD & 0.39 & 1.00 & & & \\
\hline $\begin{array}{l}\text { Un-weighted } \\
\text { linear average }\end{array}$ & 0.49 & 0.83 & 1.00 & & \\
\hline $\begin{array}{l}\text { Weighted linear } \\
\text { average }\end{array}$ & 0.52 & 0.68 & 0.83 & 1.00 & \\
\hline $\begin{array}{l}\text { Weighted } \\
\text { geometric } \\
\text { average }\end{array}$ & 0.52 & 0.57 & 0.77 & 0.89 & 1.00 \\
\hline
\end{tabular}




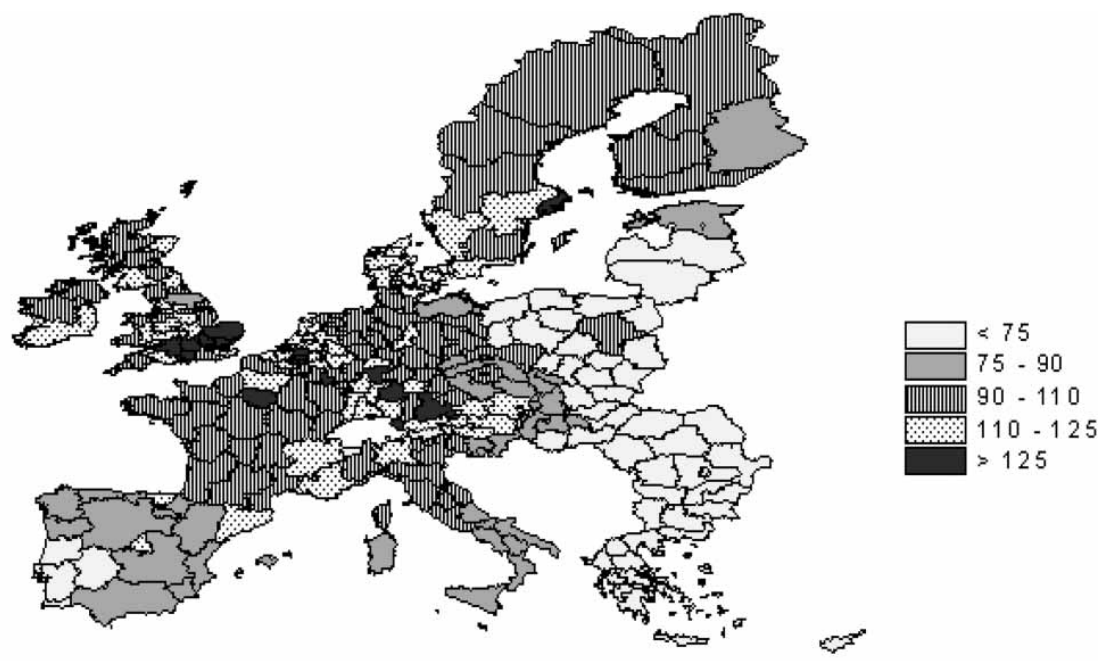

$\therefore a r a f$

Figure 2. Weighted linear average FDI Potential Index $(E U=100)$.

that any one of these three new FDI Potential indices offers a more accurate view of the regional FDI attractiveness than the UNCTAD index.

Concerning the three new indices, it seems that the weighted linear average index performs better than the un-weighted, while the weighted linear and weighted geometric ones get roughly the same values. In view of this, we opt for picking out the weighted linear average version of the Potential Index (hereafter called "POI") for our comments and further analysis.

The results obtained are shown in Figure $2 .{ }^{14}$ It can be observed that the most attractive regions are mainly located in the UK, among which Inner London, Berkshire, Bucks and Oxfordshire, and Bedfordshire and Hertfordshire stand out. Along with these, other regions exhibiting a high FDI attractiveness are Île de France, Luxembourg, Antwerp, Oberbayern, Vlaams Brabant, Stuttgart, Brabant Wallon and Stockholm. On the contrary, most of the Greek regions are not very attractive for FDI (in particular Dytiki Ellada, Dytiki Makedonia and Ipeiros), a trait that is also shared by some Polish (Swietokrzyskie and Lubelskie), Bulgarian (Severoiztochen and Severen Tsentralen) and Romanian (Sud-Est and Nord-Est) regions. On the whole these findings seem to reflect something of a North-South pattern.

\section{Applying UNCTAD FDI Typology to the EU Regions}

As mentioned in the Introduction, UNCTAD (2002) proposed the use of two indicators to measure the relative FDI performance and attractiveness of an economy: the Performance Index and the Potential Index. After computing the new POI, this paper uses the FDI database provided by Polasek and Sellner to calculate the Performance Index (hereafter 
"PEI"). The results obtained are not displayed here to save space, but they are available upon request.

Although the PEI is interesting in itself, UNCTAD considers, and here it is agreed, that it is much more "useful to compare the rankings based on the two indices as a rough guide to whether countries (regions in our case) are performing adequately given their (restricted set of) structural assets" (UNCTAD, 2002, p. 29). The combination of the two (Potential and Performance) FDI indices yields a $2 * 2$ matrix, according to which host economies may be considered as "front-runners" (high potential and high performance), "above-potential" economies (low potential and high performance), "below-potential" economies (high potential and low performance) or "under-performers" (low potential and low performance). ${ }^{15}$

The application of this classification to the EU regions when using the "PEI" and the "POI"-yields the results reported in Figure 3. From their consideration, the following main conclusions can be drawn: ${ }^{16}$

(1) Most of the 57 "front-runner" regions are located in the UK (16). It is also quite remarkable that most of the Belgian regions are considered front-runners (10 of 11 ), this being also the case for Swedish (5 of 8) and Dutch (6 of 12) regions. Denmark, Luxembourg and five French regions are also included in this group.

(2) There is a group of 38 "above-potential" regions, highlighting the presence of a significant share of Hungarian (7 of 8), Bulgarian (4 of 6), Polish (10 of 16), Slovakian (3 of 5) and Spanish (7 of 19) regions.
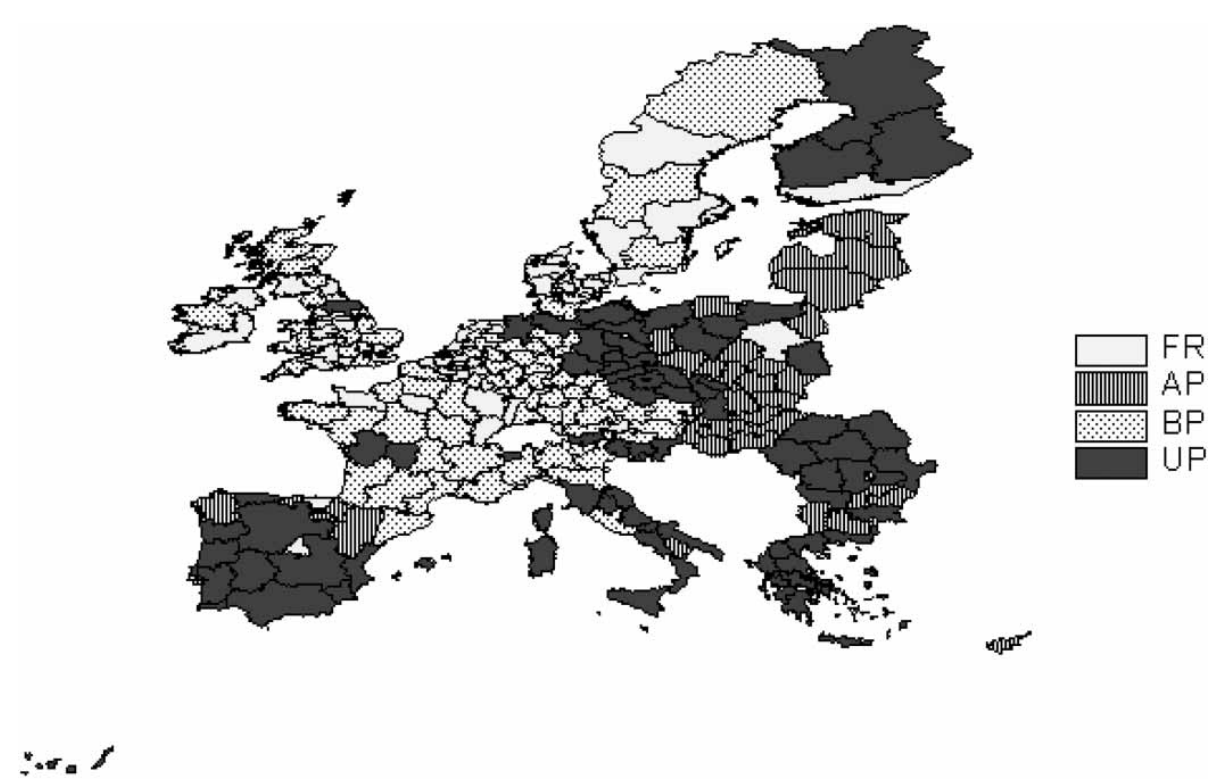

Figure 3. Regional classification by FDI Performance Index and FDI Potential Index (weighted linear average version).

Note: $\mathrm{FR}=$ Front-runner; $\mathrm{AB}=$ Above-potential; $\mathrm{BP}=$ Below-potential; $\mathrm{UP}=$ Under-performer. 
(3) The "below-potential" label may be assigned to 85 regions, including mostly German (27), British (20) and French (14) regions. A notable portion of Austrian (5 of 8), Dutch (6 of 12) and Italian (7 of 21) regions are also included in this group.

(4) The remaining 80 regions may be designated as "under-performers". This group includes all the Greek regions (13), as well as a quite remarkable share of regions belonging to Germany (10 of 39), Spain ( 9 of 19), Italy (13 of 21), Romania (7 of 8 ) and Portugal (4 of 5).

(5) Another important conclusion is that the four groups of regions are very concentrated from a geographical point of view.

\section{The New FDI Potential Index and the Role of Space}

In this section, and to assist us in deriving proper policy implications, we try to enrich the analysis by introducing the role played by space. The reason for which we deal with this issue is twofold. First, because we want to address the point that regions mainly compete against those that are closer to them from a geographical point of view; therefore, what is important for a region is not only to know its general FDI attractiveness but also its attractiveness regarding its neighbours. ${ }^{17}$ Second because, as the previous analysis reveals the existence of clear signs of polarization in the UNCTAD FDI typology, there may be, in fact, important differences between the general FDI attractiveness of a region and its attractiveness with respect to its main competitors. In consequence, we believe that, without explicitly taking into consideration the geographic situation of each region, policy implications could be somewhat marred.

To introduce space in the analysis, first we have to choose a distance matrix. We use, as for computing market potential variable, the square of the inverse of the standardized distance as a distance matrix. Then, we calculate the "Spatial-Relative FDI Potential Index" ("SRPOI") for each region as follows:

$$
\operatorname{SRPOI}_{i}=\frac{\mathrm{POI}_{i}}{\sum_{j=1}^{n} w_{i j} * \mathrm{POI}_{j}} .
$$

In this way, we compare the "POI" of each region to a weighted average of the "POI" of the remaining regions, weights being given by a distance-decay function. The interpretation of the index is obvious: a value higher (lower) than one indicates a strong (weak) position in terms of FDI attractiveness relative to the neighbouring regions.

In addition, and in order to have the full picture, we also use Equation (2) for:

(a) Computing what we call the "Spatial-Relative FDI Performance Index" ("SRPEI"); to do that, we change "POI" by "PEI" in Equation (2).

(b) Calculating the relative situation of each region for each one of the six factors used to build the "POI"; in this case we change "POI" by each factor.

The results obtained are summarized in Table 6. This table reveals: first and for the sake of comparison, the general classification according to UNCTAD typology for each region (also displayed in Figure 3); second, the relative position of each region with reference to the com- 
Table 6. Spatial-relative FDI potential ("SRPOI") and performance ("SRPEI") indices, spatial classification and weakest factors

\begin{tabular}{|c|c|c|c|c|c|c|}
\hline Region & General Class. & SRPOI & SRPEI & Spatial Class. & Weakest F. & 2nd Weakest F. \\
\hline Burgenland (A) & FR & 1.11 & 0.65 & $\mathrm{BP}$ & Technological progress & Market size \\
\hline Niederösterreich & $\mathrm{BP}$ & 1.14 & 0.45 & $\mathrm{BP}$ & Technological progress & Labour regulation \\
\hline Wien & FR & 1.21 & 1.08 & FR & Competitiveness & Labour situation \\
\hline Kärnten & $\mathrm{BP}$ & 1.14 & 0.89 & $\mathrm{BP}$ & Market size & Technological progress \\
\hline Steiermark & $\mathrm{BP}$ & 1.12 & 0.72 & $\mathrm{BP}$ & Market size & Competitiveness \\
\hline Oberösterreich & $\mathrm{BP}$ & 1.16 & 0.74 & $\mathrm{BP}$ & Technological progress & Market size \\
\hline Salzburg & FR & 1.12 & 1.26 & FR & Market size & Technological progress \\
\hline Tirol & $\mathrm{BP}$ & 1.21 & 1.09 & FR & Market size & Competitiveness \\
\hline Vorarlberg & FR & 1.17 & 1.74 & FR & Market size & Technological progress \\
\hline Région de Bruxelles-Capitale & FR & 1.26 & 1.57 & FR & Labour situation & Competitiveness \\
\hline Prov. Antwerpen & FR & 1.06 & 1.66 & FR & Labour situation & Technological progress \\
\hline Prov. Limburg (B) & FR & 1.01 & 2.09 & FR & Technological progress & Labour situation \\
\hline Prov. Oost-Vlaanderen & FR & 0.99 & 0.80 & UP & Labour situation & Economic potential \\
\hline Prov. Vlaams Brabant & FR & 0.95 & 1.64 & AP & Market size & Technological progress \\
\hline Prov. West-Vlaanderen & FR & 1.05 & 1.77 & FR & Technological progress & Market size \\
\hline Prov. Brabant Wallon & FR & 0.99 & 0.50 & UP & Market size & Labour situation \\
\hline Prov. Hainaut & FR & 0.94 & 0.69 & UP & Labour situation & Technological progress \\
\hline Prov. Liège & FR & 0.96 & 1.06 & $\mathrm{AP}$ & Labour situation & Market size \\
\hline Prov. Luxembourg (B) & $\mathrm{BP}$ & 0.95 & 0.28 & UP & Technological progress & Labour situation \\
\hline Prov. Namur & FR & 0.91 & 1.18 & $\mathrm{AP}$ & Labour situation & Market size \\
\hline Severozapaden & UP & 0.95 & 0.15 & UP & Labour situation & Technological progress \\
\hline Severen tsentralen & AP & 0.85 & 0.92 & UP & Economic potential & Labour situation \\
\hline Severoiztochen & $\mathrm{AP}$ & 0.84 & 2.27 & $\mathrm{AP}$ & Economic potential & Labour situation \\
\hline Yugoiztochen & UP & 0.94 & 0.38 & UP & Labour situation & Technological progress \\
\hline Yugozapaden & AP & 0.91 & 8.76 & AP & Economic potential & Competitiveness \\
\hline Yuzhen tsentralen & $\mathrm{AP}$ & 0.90 & 0.97 & UP & Economic potential & Technological progress \\
\hline Cyprus & AP & 0.87 & 2.98 & $\mathrm{AP}$ & Competitiveness & Market size \\
\hline Praha & FR & 1.24 & 8.24 & FR & Economic potential & Competitiveness \\
\hline Strední Cechy & UP & 1.00 & 0.33 & UP & Technological progress & Economic potential \\
\hline Jihozápad & UP & 0.85 & 0.32 & UP & Economic potential & Technological progress \\
\hline Severozápad & UP & 0.87 & 0.46 & UP & Technological progress & Economic potential \\
\hline Severovýchod & UP & 0.91 & 0.38 & UP & Economic potential & Technological progress \\
\hline
\end{tabular}




\begin{tabular}{|c|c|c|c|c|c|c|}
\hline Jihovýchod & UP & 0.87 & 0.36 & UP & Economic potential & Labour situation \\
\hline Strední Morava & UP & 0.97 & 0.45 & UP & Economic potential & Technological progress \\
\hline Moravskoslezsko & UP & 0.96 & 0.42 & UP & Economic potential & Technological progress \\
\hline Stuttgart & $\mathrm{BP}$ & 1.16 & 0.78 & $\mathrm{BP}$ & Labour regulation & Economic potential \\
\hline Karlsruhe & $\mathrm{BP}$ & 1.10 & 0.85 & $\mathrm{BP}$ & Labour regulation & Economic potential \\
\hline Freiburg & $\mathrm{BP}$ & 1.04 & 0.70 & $\mathrm{BP}$ & Labour regulation & Technological progress \\
\hline Tübingen & $\mathrm{BP}$ & 1.06 & 0.79 & $\mathrm{BP}$ & Labour regulation & Market size \\
\hline Oberbayern & $\mathrm{BP}$ & 1.24 & 0.93 & $\mathrm{BP}$ & Labour regulation & Competitiveness \\
\hline Niederbayern & $\mathrm{BP}$ & 1.01 & 0.48 & $\mathrm{BP}$ & Labour regulation & Market size \\
\hline Oberpfalz & $\mathrm{BP}$ & 1.02 & 0.48 & $\mathrm{BP}$ & Labour regulation & Market size \\
\hline Oberfranken & $\mathrm{BP}$ & 0.98 & 0.44 & UP & Labour regulation & Technological progress \\
\hline Mittelfranken & $\mathrm{BP}$ & 1.09 & 0.76 & $\mathrm{BP}$ & Labour regulation & Market size \\
\hline Unterfranken & $\mathrm{BP}$ & 0.99 & 0.69 & UP & Labour regulation & Market size \\
\hline Schwaben & $\mathrm{BP}$ & 0.98 & 0.66 & UP & Labour regulation & Technological progress \\
\hline Berlin & $\mathrm{BP}$ & 1.10 & 1.31 & FR & Labour regulation & Competitiveness \\
\hline Brandenburg-Nordost & UP & 0.93 & 0.48 & UP & Technological progress & Labour situation \\
\hline Brandenburg-Südwest & UP & 0.95 & 0.67 & UP & Labour regulation & Technological progress \\
\hline Bremen & FR & 1.01 & 1.36 & FR & Labour regulation & Market size \\
\hline Hamburg & FR & 1.13 & 3.66 & FR & Labour regulation & Competitiveness \\
\hline Darmstadt & $\mathrm{BP}$ & 1.15 & 0.71 & $\mathrm{BP}$ & Labour regulation & Competitiveness \\
\hline Gießen & $\mathrm{BP}$ & 1.00 & 0.83 & UP & Market size & Labour situation \\
\hline Kassel & $\mathrm{BP}$ & 0.94 & 0.53 & UP & Labour regulation & Technological progress \\
\hline Mecklenburg-Vorpommern & UP & 0.87 & 0.26 & UP & Labour regulation & Competitiveness \\
\hline Braunschweig & $\mathrm{BP}$ & 1.12 & 0.32 & $\mathrm{BP}$ & Labour regulation & Market size \\
\hline Hannover & $\mathrm{BP}$ & 1.02 & 0.48 & $\mathrm{BP}$ & Labour regulation & Technological progress \\
\hline Lüneburg & UP & 0.89 & 0.25 & UP & Labour situation & Technological progress \\
\hline Weser-Ems & UP & 0.92 & 0.46 & UP & Labour regulation & Technological progress \\
\hline Düsseldorf & $\mathrm{BP}$ & 1.04 & 0.34 & $\mathrm{BP}$ & Labour regulation & Technological progress \\
\hline Köln & $\mathrm{BP}$ & 1.06 & 0.62 & $\mathrm{BP}$ & Labour regulation & Competitiveness \\
\hline Münster & $\mathrm{BP}$ & 0.94 & 0.58 & UP & Labour regulation & Technological progress \\
\hline Detmold & $\mathrm{BP}$ & 0.97 & 0.59 & UP & Labour regulation & Technological progress \\
\hline Arnsberg & $\mathrm{BP}$ & 0.99 & 0.39 & UP & Labour regulation & Technological progress \\
\hline Koblenz & $\mathrm{BP}$ & 0.93 & 0.51 & UP & Technological progress & Labour regulation \\
\hline Trier & $\mathrm{BP}$ & 0.89 & 0.37 & UP & Labour regulation & Market size \\
\hline
\end{tabular}


Table 6. Continued

\begin{tabular}{|c|c|c|c|c|c|c|}
\hline Region & General Class. & SRPOI & SRPEI & Spatial Class. & Weakest F. & 2nd Weakest F. \\
\hline Rheinhessen-Pfalz & $\mathrm{BP}$ & 1.03 & 0.65 & $\mathrm{BP}$ & Labour regulation & Labour situation \\
\hline Saarland & $\mathrm{BP}$ & 0.94 & 0.34 & UP & Labour regulation & Market size \\
\hline Chemnitz & UP & 0.91 & 0.68 & UP & Labour regulation & Competitiveness \\
\hline Dresden & UP & 1.01 & 0.73 & $\mathrm{BP}$ & Labour regulation & Competitiveness \\
\hline Leipzig & UP & 0.97 & 0.41 & UP & Labour regulation & Market size \\
\hline Sachsen-Anhalt & UP & 0.91 & 0.56 & UP & Labour regulation & Technological progress \\
\hline Schleswig-Holstein & $\mathrm{BP}$ & 0.95 & 0.19 & UP & Technological progress & Labour regulation \\
\hline Thüringen & UP & 0.92 & 0.81 & UP & Labour regulation & Economic potential \\
\hline Hovedstaden & FR & 1.10 & 1.04 & FR & Market size & Competitiveness \\
\hline Estonia & AP & 0.87 & 2.66 & AP & Economic potential & Market size \\
\hline Galicia & AP & 0.85 & 1.40 & $\mathrm{AP}$ & Competitiveness & Labour situation \\
\hline Principado de Asturias & UP & 0.83 & 0.83 & UP & Labour situation & Market size \\
\hline Cantabria & AP & 0.85 & 1.32 & AP & Market size & Labour regulation \\
\hline Pais Vasco & FR & 1.26 & 1.00 & $\mathrm{BP}$ & Labour regulation & Economic potential \\
\hline Comunidad Foral de Navarra & AP & 0.92 & 1.12 & AP & Market size & Labour regulation \\
\hline La Rioja & AP & 0.83 & 1.66 & AP & Market size & Technological progress \\
\hline Aragón & $\mathrm{AP}$ & 0.87 & 1.96 & AP & Market size & Labour regulation \\
\hline Comunidad de Madrid & FR & 1.41 & 1.89 & FR & Economic potential & Competitiveness \\
\hline Castilla y León & UP & 0.81 & 0.49 & UP & Competitiveness & Labour situation \\
\hline Castilla-la Mancha & UP & 0.81 & 0.24 & UP & Technological progress & Market size \\
\hline Extremadura & UP & 0.82 & 0.03 & UP & Labour situation & Market size \\
\hline Cataluña & $\mathrm{BP}$ & 1.22 & 0.69 & BP & Economic potential & Labour regulation \\
\hline Comunidad Valenciana & UP & 0.89 & 0.67 & UP & Economic potential & Labour regulation \\
\hline Illes Balears & UP & 0.85 & 0.31 & UP & Competitiveness & Technological progress \\
\hline Andalucia & UP & 0.89 & 0.32 & UP & Labour situation & Economic potential \\
\hline Región de Murcia & UP & 0.84 & 0.46 & UP & Market size & Competitiveness \\
\hline Ciudad Autónoma de Ceuta (ES) & AP & 0.91 & 1.95 & AP & Market size & Labour situation \\
\hline Ciudad Autónoma de Melilla (ES) & AP & 0.89 & 4.11 & AP & Labour situation & Market size \\
\hline Canarias (ES) & UP & 0.78 & 0.46 & UP & Competitiveness & Labour regulation \\
\hline Itä-Suomi & UP & 0.94 & 0.60 & UP & Market size & Labour regulation \\
\hline Etelä-Suomi & FR & 1.23 & 1.18 & FR & Labour regulation & Competitiveness \\
\hline Länsi-Suomi & UP & 1.03 & 0.73 & BP & Labour regulation & Market size \\
\hline
\end{tabular}




\begin{tabular}{|c|c|c|c|c|c|c|}
\hline Pohjois-Suomi & UP & 1.06 & 0.84 & BP & Market size & Labour regulation \\
\hline Åland & UP & 0.75 & 0.33 & UP & Market size & Technological progress \\
\hline Île de France & FR & 1.34 & 2.07 & FR & Competitiveness & Economic potential \\
\hline Champagne-Ardenne & $\mathrm{BP}$ & 0.91 & 0.21 & UP & Technological progress & Labour regulation \\
\hline Picardie & BP & 0.95 & 0.18 & UP & Labour situation & Technological progress \\
\hline Haute-Normandie & BP & 0.94 & 0.57 & UP & Labour situation & Labour regulation \\
\hline Centre & $\mathrm{BP}$ & 0.98 & 0.51 & UP & Labour situation & Technological progress \\
\hline Basse-Normandie & FR & 0.90 & 0.94 & UP & Labour regulation & Technological progress \\
\hline Bourgogne & $\mathrm{BP}$ & 0.94 & 0.34 & UP & Technological progress & Market size \\
\hline Nord-Pas-de-Calais & $\mathrm{BP}$ & 0.90 & 0.33 & UP & Labour situation & Technological progress \\
\hline Lorraine & FR & 0.94 & 0.79 & UP & Labour situation & Technological progress \\
\hline Alsace & FR & 1.03 & 2.09 & FR & Labour situation & Market size \\
\hline Franche-Comté & FR & 1.01 & 1.25 & FR & Market size & Labour situation \\
\hline Pays de la Loire & $\mathrm{BP}$ & 0.97 & 0.75 & UP & Labour regulation & Technological progress \\
\hline Bretagne & BP & 0.96 & 0.74 & UP & Labour situation & Labour regulation \\
\hline Poitou-Charentes & UP & 0.93 & 0.55 & UP & Technological progress & Labour situation \\
\hline Aquitaine & BP & 1.00 & 0.55 & UP & Labour situation & Competitiveness \\
\hline Midi-Pyrénées & $\mathrm{BP}$ & 1.04 & 0.97 & $\mathrm{BP}$ & Labour situation & Competitiveness \\
\hline Limousin & UP & 0.92 & 0.55 & UP & Market size & Competitiveness \\
\hline Rhône-Alpes & BP & 1.11 & 0.60 & $\mathrm{BP}$ & Labour situation & Competitiveness \\
\hline Auvergne & $\mathrm{BP}$ & 0.96 & 0.31 & UP & Market size & Labour situation \\
\hline Languedoc-Roussillon & $\mathrm{BP}$ & 0.96 & 0.37 & UP & Labour situation & Competitiveness \\
\hline Provence-Alpes-Côte d'Azur & BP & 1.05 & 0.78 & BP & Labour situation & Competitiveness \\
\hline Corse & UP & 0.97 & 0.10 & UP & Market size & Labour situation \\
\hline Anatoliki Makedonia, Thraki & UP & 0.87 & 0.12 & UP & Competitiveness & Labour regulation \\
\hline Kentriki Makedonia & UP & 0.90 & 0.01 & UP & Competitiveness & Labour regulation \\
\hline Dytiki Makedonia & UP & 0.83 & -0.29 & UP & Competitiveness & Market size \\
\hline Thessalia & UP & 0.89 & 0.05 & UP & Competitiveness & Market size \\
\hline Ipeiros & UP & 0.84 & 0.02 & UP & Competitiveness & Market size \\
\hline Ionia Nisia & UP & 0.94 & -0.03 & UP & Technological progress & Market size \\
\hline Dytiki Ellada & UP & 0.78 & -0.23 & UP & Competitiveness & Market size \\
\hline Sterea Ellada & UP & 1.01 & 0.31 & BP & Technological progress & Labour situation \\
\hline Peloponnisos & UP & 0.99 & -0.61 & UP & Technological progress & Market size \\
\hline Attiki & UP & 1.02 & 1.46 & FR & Competitiveness & Economic potential \\
\hline
\end{tabular}


Table 6. Continued

\begin{tabular}{|c|c|c|c|c|c|c|}
\hline Region & General Class. & SRPOI & SRPEI & Spatial Class. & Weakest F. & 2nd Weakest F. \\
\hline Voreio Aigaio & UP & 0.89 & 0.04 & UP & Competitiveness & Market size \\
\hline Notio Aigaio & UP & 0.93 & 0.01 & UP & Technological progress & Market size \\
\hline Kriti & UP & 0.84 & 0.08 & UP & Competitiveness & Market size \\
\hline Közép-Magyarország & AP & 1.06 & 1.12 & FR & Economic potential & Competitiveness \\
\hline Közép-Dunántúl & AP & 1.02 & 1.20 & FR & Economic potential & Technological progress \\
\hline Nyugat-Dunántúl & AP & 0.92 & 1.05 & AP & Economic potential & Technological progress \\
\hline Dél-Dunántúl & $\mathrm{AP}$ & 0.82 & 1.02 & $\mathrm{AP}$ & Labour situation & Market size \\
\hline Észak-Magyarország & AP & 0.96 & 0.96 & UP & Labour situation & Technological progress \\
\hline Észak-Alföld & AP & 0.93 & 1.92 & AP & Labour situation & Market size \\
\hline Dél-Alföld & AP & 0.88 & 0.97 & UP & Labour situation & Market size \\
\hline Border, Midlands and Western & BP & 0.94 & 0.48 & UP & Market size & Labour situation \\
\hline Southern and Eastern & FR & 1.11 & 1.80 & FR & Economic potential & Labour situation \\
\hline Piemonte & $\mathrm{BP}$ & 1.12 & 0.63 & $\mathrm{BP}$ & Labour situation & Economic potential \\
\hline Valle d'Aosta/Vallée d'Aoste & UP & 0.69 & 0.07 & UP & Market size & Technological progress \\
\hline Liguria & BP & 0.98 & 0.55 & UP & Labour situation & Market size \\
\hline Lombardia & $\mathrm{BP}$ & 1.15 & 0.27 & $\mathrm{BP}$ & Technological progress & Economic potential \\
\hline Provincia Autonoma Bolzano-Bozen & UP & 0.68 & 0.32 & UP & Technological progress & Market size \\
\hline Provincia Autonoma Trento & $\mathrm{BP}$ & 1.04 & 0.86 & $\mathrm{BP}$ & Market size & Competitiveness \\
\hline Veneto & $\mathrm{BP}$ & 1.07 & 0.52 & $\mathrm{BP}$ & Technological progress & Economic potential \\
\hline Friuli-Venezia Giulia & UP & 0.97 & 0.54 & UP & Market size & Competitiveness \\
\hline Emilia-Romagna & $\mathrm{BP}$ & 1.04 & 0.45 & $\mathrm{BP}$ & Economic potential & Competitiveness \\
\hline Toscana & UP & 0.98 & 0.40 & UP & Competitiveness & Labour situation \\
\hline Umbria & UP & 0.94 & 0.26 & UP & Market size & Competitiveness \\
\hline Marche & UP & 0.96 & 1.63 & AP & Technological progress & Labour regulation \\
\hline Lazio & BP & 1.10 & 0.47 & BP & Labour situation & Competitiveness \\
\hline Abruzzo & UP & 0.96 & 0.66 & UP & Market size & Labour situation \\
\hline Molise & UP & 0.92 & 0.64 & UP & Market size & Labour situation \\
\hline Campania & UP & 0.98 & 0.55 & UP & Labour situation & Competitiveness \\
\hline Puglia & UP & 0.97 & 0.26 & UP & Labour situation & Competitiveness \\
\hline Basilicata & $\mathrm{AP}$ & 0.98 & 2.33 & $\mathrm{AP}$ & Market size & Labour situation \\
\hline Calabria & UP & 0.93 & 0.18 & UP & Labour situation & Competitiveness \\
\hline Sicilia & UP & 0.93 & 0.09 & UP & Labour situation & Competitiveness \\
\hline
\end{tabular}

Magyarország

Dél-Alföld

ern and Easter

Valle d'Aosta/Vallée d'Aoste

Provincia Autonoma Bolzano-Bozen

Friuli-Venezia Giulia

Campania

$\begin{array}{lll}0.93 & 0.09 \quad \text { UP }\end{array}$ 


\begin{tabular}{|c|c|c|c|c|c|c|}
\hline Sardegna & UP & 0.86 & 0.34 & UP & Labour situation & Competitiveness \\
\hline Lithuania & AP & 0.82 & 1.07 & AP & Economic potential & Labour regulation \\
\hline Luxembourg & FR & 1.25 & 3.24 & FR & Market size & Competitiveness \\
\hline Latvia & $\mathrm{AP}$ & 0.78 & 0.92 & UP & Economic potential & Competitiveness \\
\hline Malta & $\mathrm{AP}$ & 0.99 & 4.10 & $\mathrm{AP}$ & Labour situation & Market size \\
\hline Groningen & $\mathrm{BP}$ & 0.97 & 0.19 & UP & Market size & Competitiveness \\
\hline Friesland (NL) & FR & 0.90 & 0.85 & UP & Technological progress & Market size \\
\hline Drenthe & FR & 0.97 & 2.19 & $\mathrm{AP}$ & Technological progress & Market size \\
\hline Overijssel & BP & 0.98 & 0.35 & UP & Market size & Economic potential \\
\hline Gelderland & $\mathrm{BP}$ & 0.99 & 0.73 & UP & Economic potential & Technological progress \\
\hline Flevoland & $\mathrm{BP}$ & 1.00 & 0.62 & $\mathrm{BP}$ & Market size & Economic potential \\
\hline Utrecht & FR & 1.04 & 0.97 & BP & Competitiveness & Market size \\
\hline Noord-Holland & FR & 1.05 & 1.37 & FR & Competitiveness & Labour regulation \\
\hline Zuid-Holland & FR & 1.00 & 0.86 & UP & Competitiveness & Technological progress \\
\hline Zeeland & FR & 0.95 & 1.06 & AP & Technological progress & Market size \\
\hline Noord-Brabant & $\mathrm{BP}$ & 1.02 & 0.23 & $\mathrm{BP}$ & Economic potential & Technological progress \\
\hline Limburg (NL) & $\mathrm{BP}$ & 1.01 & 0.34 & $\mathrm{BP}$ & Market size & Economic potential \\
\hline Lódzkie & $\mathrm{AP}$ & 0.78 & 1.05 & $\mathrm{AP}$ & Economic potential & Competitiveness \\
\hline Mazowieckie & FR & 1.44 & 1.16 & FR & Economic potential & Competitiveness \\
\hline Malopolskie & $\mathrm{AP}$ & 0.84 & 1.41 & AP & Economic potential & Competitiveness \\
\hline Slaskie & $\mathrm{AP}$ & 0.85 & 1.00 & $\mathrm{AP}$ & Labour situation & Economic potential \\
\hline Lubelskie & UP & 0.75 & 0.59 & UP & Economic potential & Competitiveness \\
\hline Podkarpackie & $\mathrm{AP}$ & 0.82 & 0.98 & UP & Economic potential & Technological progress \\
\hline Swietokrzyskie & $\mathrm{AP}$ & 0.74 & 0.77 & UP & Economic potential & Competitiveness \\
\hline Podlaskie & AP & 0.74 & 0.94 & UP & Economic potential & Competitiveness \\
\hline Wielkopolskie & UP & 0.80 & 0.90 & UP & Economic potential & Competitiveness \\
\hline Zachodniopomorskie & UP & 0.72 & 0.77 & UP & Labour situation & Economic potential \\
\hline Lubuskie & $\mathrm{AP}$ & 0.74 & 1.16 & $\mathrm{AP}$ & Economic potential & Technological progress \\
\hline Dolnoslaskie & AP & 1.04 & 0.88 & $\mathrm{BP}$ & Labour situation & Economic potential \\
\hline Opolskie & AP & 0.79 & 1.39 & AP & Labour situation & Market size \\
\hline Kujawsko-Pomorskie & UP & 0.80 & 0.44 & UP & Economic potential & Technological progress \\
\hline Warminsko-Mazurskie & UP & 0.75 & 0.76 & UP & Labour situation & Economic potential \\
\hline Pomorskie & $\mathrm{AP}$ & 0.86 & 1.07 & $\mathrm{AP}$ & Labour situation & Economic potential \\
\hline Norte & UP & 0.86 & 0.70 & UP & Economic potential & Technological progress \\
\hline
\end{tabular}


Table 6. Continued

\begin{tabular}{|c|c|c|c|c|c|c|}
\hline Region & General Class. & SRPOI & SRPEI & Spatial Class. & Weakest F. & 2nd Weakest F. \\
\hline Algarve & UP & 0.84 & 0.72 & UP & Market size & Competitiveness \\
\hline Centro (PT) & UP & 0.83 & 0.72 & UP & Economic potential & Technological progress \\
\hline Lisboa & FR & 1.30 & 2.37 & FR & Competitiveness & Economic potential \\
\hline Alentejo & UP & 0.83 & 0.50 & UP & Market size & Technological progress \\
\hline Nord-Vest & UP & 0.82 & 0.45 & UP & Economic potential & Technological progress \\
\hline Centru & UP & 0.86 & 0.46 & UP & Economic potential & Technological progress \\
\hline Nord-Est & UP & 0.82 & 0.19 & UP & Economic potential & Technological progress \\
\hline Sud-Est & UP & 0.89 & 0.27 & UP & Economic potential & Technological progress \\
\hline Sud-Muntenia & UP & 0.97 & 0.12 & UP & Economic potential & Technological progress \\
\hline Bucuresti-Ilfov & $\mathrm{AP}$ & 0.96 & 5.29 & $\mathrm{AP}$ & Economic potential & Competitiveness \\
\hline Sud-Vest Oltenia & UP & 0.84 & 0.27 & UP & Economic potential & Technological progress \\
\hline Vest & UP & 0.84 & 0.13 & UP & Economic potential & Technological progress \\
\hline Stockholm & FR & 1.35 & 3.47 & FR & Competitiveness & Labour regulation \\
\hline Östra Mellansverige & FR & 1.09 & 0.81 & $\mathrm{BP}$ & Market size & Labour regulation \\
\hline Småland med öarna & $\mathrm{BP}$ & 1.05 & 0.77 & $\mathrm{BP}$ & Labour regulation & Technological progress \\
\hline Sydsverige & FR & 1.15 & 1.11 & FR & Market size & Labour regulation \\
\hline Västsverige & FR & 1.14 & 1.06 & FR & Labour regulation & Market size \\
\hline Norra Mellansverige & $\mathrm{BP}$ & 1.02 & 0.77 & $\mathrm{BP}$ & Market size & Labour regulation \\
\hline Mellersta Norrland & FR & 1.04 & 1.11 & FR & Market size & Labour regulation \\
\hline Övre Norrland & $\mathrm{BP}$ & 1.04 & 0.53 & $\mathrm{BP}$ & Market size & Labour regulation \\
\hline Slovenia & UP & 0.85 & 0.70 & UP & Economic potential & Labour regulation \\
\hline Bratislavský kraj & AP & 0.91 & 7.40 & AP & Economic potential & Market size \\
\hline Západné Slovensko & UP & 0.87 & 0.42 & UP & Economic potential & Technological progress \\
\hline Stredné Slovensko & AP & 0.88 & 1.04 & $\mathrm{AP}$ & Economic potential & Technological progress \\
\hline Východné Slovensko & AP & 0.93 & 1.23 & AP & Economic potential & Technological progress \\
\hline Tees Valley and Durham & FR & 1.01 & 1.78 & FR & Labour situation & Technological progress \\
\hline Northumberland, Tyne and Wear & FR & 1.01 & 1.03 & FR & Labour situation & Competitiveness \\
\hline Cumbria & $\mathrm{BP}$ & 0.94 & 0.32 & UP & Market size & Technological progress \\
\hline Cheshire & FR & 0.90 & 1.19 & $\mathrm{AP}$ & Market size & Labour regulation \\
\hline Greater Manchester & $\mathrm{BP}$ & 1.05 & 0.57 & $\mathrm{BP}$ & Technological progress & Competitiveness \\
\hline Lancashire & FR & 1.04 & 1.79 & FR & Market size & Economic potential \\
\hline Merseyside & FR & 0.99 & 0.99 & UP & Labour situation & Competitiveness \\
\hline
\end{tabular}


East Yorkshire and Northern Lincolnshire

North Yorkshire

South Yorkshire

West Yorkshire

Derbyshire and Nottinghamshire

Leicestershire, Rutland and Northants

Lincolnshire

Herefordshire, Worcestershire and Warks

Shropshire and Staffordshire

West Midlands

East Anglia

Bedfordshire, Hertfordshire

Essex

Inner London

Outer London

Berkshire, Bucks and Oxfordshire

Surrey, East and West Sussex

Kent

Gloucestershire, Wiltshire and Bristol

Dorset and Somerset

Cornwall and Isles of Scilly

Devon

West Wales and The Valleys

East Wales

Eastern Scotland

South Western Scotland

North Eastern Scotland

Highlands and Islands

Northern Ireland
Hampshire and Isle of Wight

$\begin{array}{llll}\text { BP } & 0.96 & 0.83 & \text { UP } \\ \text { UP } & 0.78 & 0.38 & \text { UP } \\ \text { BP } & 0.97 & 0.85 & \text { UP } \\ \text { BP } & 1.05 & 0.58 & \text { BP } \\ \text { FR } & 1.05 & 1.26 & \text { FR } \\ \text { BP } & 1.02 & 0.65 & \text { BP } \\ \text { BP } & 0.92 & 0.22 & \text { UP } \\ \text { FR } & 1.02 & 0.86 & \text { BP } \\ \text { FR } & 0.99 & 0.84 & \text { UP } \\ \text { FR } & 1.02 & 2.45 & \text { FR } \\ \text { BP } & 1.06 & 0.66 & \text { BP } \\ \text { BP } & 1.10 & 0.92 & \text { BP } \\ \text { FR } & 1.03 & 0.99 & \text { BP } \\ \text { BP } & 1.23 & 0.92 & \text { BP } \\ \text { BP } & 0.98 & 0.94 & \text { UP } \\ \text { BP } & 1.18 & 0.83 & \text { BP } \\ \text { BP } & 0.82 & 0.63 & \text { UP } \\ \text { FR } & 1.07 & 1.25 & \text { FR } \\ \text { FR } & 0.98 & 1.07 & \text { AP } \\ \text { FR } & 1.11 & 1.84 & \text { FR } \\ \text { FR } & 0.96 & 0.96 & \text { UP } \\ \text { BP } & 0.91 & 0.58 & \text { UP } \\ \text { BP } & 0.96 & 0.69 & \text { UP } \\ \text { BP } & 0.93 & 0.40 & \text { UP } \\ \text { BP } & 1.04 & 0.72 & \text { BP } \\ \text { BP } & 0.99 & 0.49 & \text { UP } \\ \text { FR } & 1.02 & 1.42 & \text { FR } \\ \text { BP } & 1.09 & 0.92 & \text { BP } \\ \text { BP } & 0.92 & 0.08 & \text { UP } \\ \text { FR } & 0.97 & 1.03 & \text { AP }\end{array}$

Note: $\mathrm{FR}=$ front-runner; $\mathrm{AB}=$ above-potential; $\mathrm{BP}=$ below-potential and $\mathrm{UP}=$ under-performer.
Technological progress Labour situation

Market size

Labour situation

Technological progress

Labour situation

Market size

Technological progress

Market size

Competitiveness

Market size

Competitiveness

Labour regulation

Technological progress

Technological progress

Labour situation

Market size

Market size

Market size

Technological progress

Economic potential

Economic potential

Economic potential

Labour situation

Labour situation

Labour regulation

Competitiveness

Technological progress

Competitiveness

Economic potential

Market size

Technological progress Market size

Market size

Economic potential

Labour situation

Competitiveness

Labour situation

Market size

Economic potential

Technological progress

Technological progress

Competitiveness

Technological progress

Competitiveness

Technological progress

Competitiveness

Competitiveness

Economic potential

Technological progress 


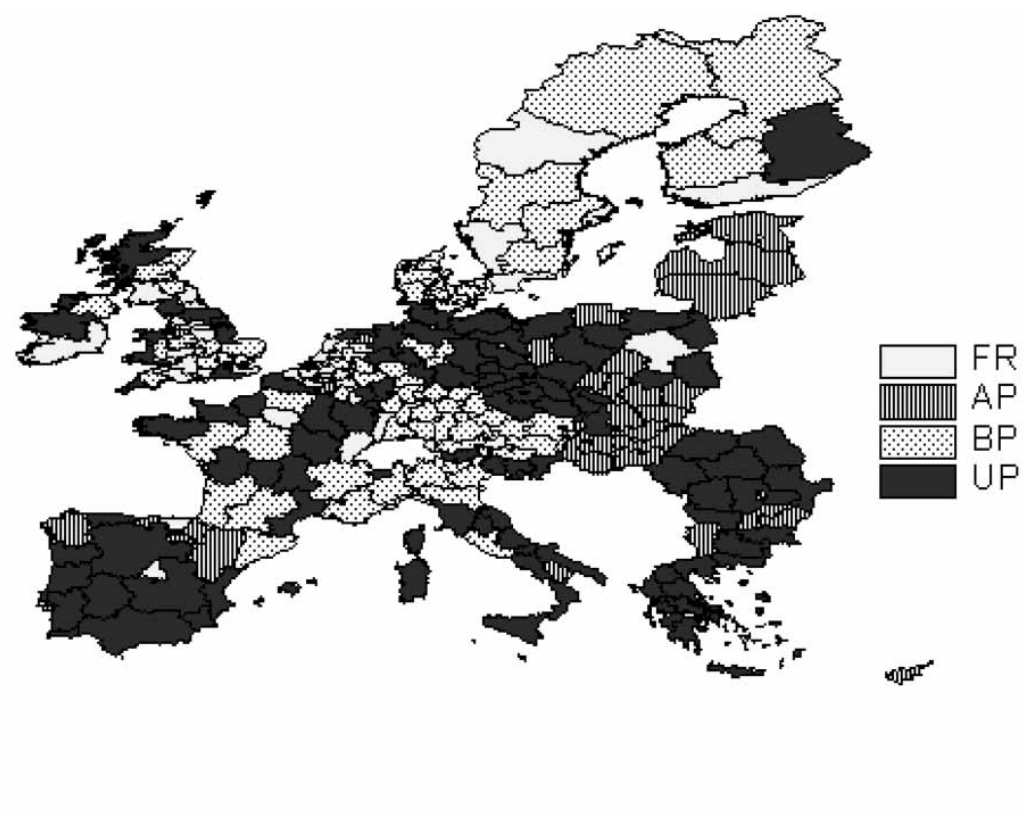

Figure 4. Regional classification by spatial-relative FDI Performance Index and spatial-relative FDI Potential Index (weighted linear average version).

Note: $\mathrm{FR}=$ front-runner; $\mathrm{AB}=$ above-potential; $\mathrm{BP}=$ below-potential and $\mathrm{UP}=$ under-performer.

peting regions for both the "POI" and the "PEI" (that is, the "SRPOI" and "SRPEI"); third, the new classification when space is included (called spatial classification) and fourth, the two factors in which each region is relatively weak compared to its neighbours. ${ }^{18}$

The first and most important conclusion is that the inclusion of space significantly modifies the results for some regions; this implies that space matters, and it matters a lot. Concerning the "SRPOI", it turns out that now the regions showing the highest scores are Mazowieckie, Madrid, Stockholm, Ile de France and Lisbon, whereas those with the lowest scores are Bolzano, Valle d'Aosta, Zachodniopomorskie, Lubuskie and Podlaskie. With respect to the UNCTAD typology, there are also quite a few changes between the results obtained for the general (Figure 3) and spatial classifications (Figure 4). Changes in UK regions are especially remarkable. Using the Dorset and Somerset regions as an example, it can be seen that it switches from the "front-runner" to the "under-performer" group. In other words, its situation is not as good as it seemed to be; this region is in a weaker position than its neighbours, especially in terms of "labour conditions" and "technological progress". In addition, it can be seen that, as expected, each one of the four UNCTAD typology groups is now (when the role of space is explicitly considered) less geographically concentrated than before (when the role of space was not taken into account).

Regarding the two relatively weakest factors of each region (see the last two columns of Table 6), another important conclusion is the existence of a great variety of situations, which, from a political point of view, implies that a European-wide policy would not be the best approach to promote FDI at a regional level. Trying to find some common pat- 
terns, however, it could be said that policies for "below-potential" regions should be mainly aimed at fostering "labour regulation", "market size" and "competitiveness" factors. A pattern also exists, although less markedly, for the "under-performer" regions, for which the emphasis should fall on improving their "economic potential" and "labour situation" factors. As for the other two groups ("above potential" and "front-runner" regions), it is not possible to observe any common trait; therefore, we believe that regional tailor-made measures should be implemented in these cases. Table 6 could help in this task as it shows the weak points of each EU region.

\section{Conclusions}

This paper proposes what we consider to be a somewhat new, more inclusive and informative method of computing the FDI Potential Index. The proposal, based on the consideration of data availability on a large number of the variables identified in the literature as key FDI driver, and on the use of both a factor analysis and a composite indicators approach, is applied to the EU regions for the period 2000-2006. In particular, the paper computes three alternative versions of the new FDI Potential Index, all of them showing better results than the UNCTAD Potential Index. Additionally, and because the previous indices provide information about the general situation of any region but not about its position regarding its main FDI competitors (complementary information that can be critical), the paper also proposes the computation of a novel spatial FDI Potential index in order to underline the role of space and help to obtain more sound policyoriented implications.

Factor analysis allows us to extract, for each region, six factors- "economic potential", "market size", "labour situation", "technological progress", "labour regulation" and "competitiveness" - among the main determinants of FDI attractiveness; afterwards we merge them into the new FDI Potential Index. The results show that the most attractive regions are mostly located in the UK, while the less attractive are in Greece. Next, and by combining the new POI and the conventional PEI, the UNCTAD typology is applied to qualify our findings. According to it, and although FDI is, to a great extent, located in regions belonging to the EU15, these regions are generally attracting less FDI than their potential; on the contrary, a significant portion of the regions in the new Member States are receiving FDI flows markedly above their potential. ${ }^{19}$

The findings obtained in this part of the paper also convey two important messages: first, the existence of a high degree of heterogeneity in FDI attractiveness across the EU regions and, second, that regions belonging to each one of the four groups making up the UNCTAD typology are highly concentrated from a geographical point of view. ${ }^{20}$

In view of this, the role of space was included in the computation of the FDI Potential Index. Put simply, the results show that space matters and, in some cases, in a quite significant way. In particular, it makes evident that some regions fully change their attractiveness degree and/or the UNCTAD group they belong to, and that the four groups of regions are much more evenly distributed than when the space is not included.

Finally, from a policy perspective, the calculation of the relative situation of each region for each factor shows that, generally speaking, no general patterns emerge. We think, therefore, that global policies are not appropriate and policy interventions should be carried out on a flexible basis; that is to say, regionally tailored measures should be implemented in most of the EU regions, an accomplishment for which the outcomes of 
this paper should be useful Apart from this conclusion, our findings (Table 6) also suggest that European-wide policies designed to foster "labour regulations" above all, but also "market size" and "competitiveness", could have a better chance of succeeding in "below-potential" regions; this is so because these factors are those in which the "below-potential" regions show the weakest performance.

\section{Acknowledgements}

We would like to thank W. Polasek and R. Sellner for providing us with the FDI regional database, the Swedish Institute for European Policy Studies (SIEPS), as well as two anonymous referees for their helpful comments and suggestions. The usual disclaimer applies.

\section{Disclosure statement}

No potential conflict of interest was reported by the authors.

\section{Notes}

1. From here on all references to FDI do really mean inward FDI.

2. As shown later in Table 1, there are also political and socio-cultural factors that affect the location of FDI. The focus here, however, is just on economic factors.

3. Rodríguez et al. (2009) also try to improve the computation of the FDI Potential Index. They do not apply, however, an endogenous way of obtaining the weights for the factors.

4. To be precise, all versions of the FDI Potential Index are weighted as there is no other possibility of computing it. By referring to the un-weighted version we make use of its conventional naming in which all the variables involved in the calculation have the same weight.

5. For a historical review of the theories of FDI see chapters 4 and 5 of Dunning and Lundan (2008).

6. This paradigm is somewhat based on the preliminary work by Hymer (1960) in that it pays attention to the reasons why some firms engage in foreign production.

7. Here, it is probably mandatory to include short comments about two alternative, and relatively novel, theories: the new theory of international trade and the so-called institutional approach. Building on the OLI paradigm, in the first one FDI is linked to variables such as market size, barriers to entry, transport costs and factor endowments. In the institutional approach, however, variables such as financial incentives, fiscal incentives and other economic incentives play a crucial role in explaining FDI.

8. MNEs motivation can lie on augmenting innovation capacities through transfers of knowledge from local firms to MNEs and vice versa, that is to say, by exploiting know-how related assets (Dunning, 2002).

9. This is, for instance, the case of the percentage of employment in high-tech sectors. Although it tries to somewhat measure the quality of human capital, it can also be misleading because, as it is the case of many MNEs, most workers here just carry out simply assembling tasks.Although there is also an additional problem with our specification of the FDI drivers - that it cannot handle the differences between vertical and horizontal FDI- this is of no relevance here as our measure of FDI includes both vertical and horizontal FDI.

10. Although in Table 1 there are more factors related to "business facilitation", we restrict our analysis to investment as it is the only one for which there are homogeneous data.

11. Not only for lack of availability but also for technical reasons when it comes to carrying out factor analysis, some potential FDI drivers were removed from the analysis: energy-manufacturing share, services share, unit labour costs, population density, corporate tax rate, \% researchers, patents, internet, urban rural typology index, legal structure and security property rights index, and business regulations index.

12. Anyway, and for the sake of robustness, the sum scores approach is also employed. The results are roughly the same. 
13. In any case, and to give a good illustration to the reader, let us take a specific region (e.g. Brussels/Region de Bruxelles) throughout the rest of the paper to show the results. Accordingly, it could be said that Brussels is characterised by its high economic potential and degree of technological progress, although shows weakness on its labour situation.

14. Appendix shows the results for the un-weighted and geometric aggregation versions of the new Potential Index.

15. The dividing value is always the (population) weighted average of each index.

16. Getting back to Brussels, it is a "front-runner" region as it presents high levels of both "PEI" and "POI".

17. Villaverde and Maza (2012), for example, found evidence for the Spanish case of the existence of negative spatial spillovers, namely if a region improves its situation in an attraction factor for FDI, nearby regions will undergo a reduction in FDI flows.

18. As for Brussels, it keeps being a "front-runner" region when its geographical situation is considered, although in this case it seems it is not exploiting all its potential as FDI hosting region. Regarding factors, its weakest point is related to the labour market.

19. This result is in line with that of a recent paper by Sass and Fifekova (2011) stating that Central and Eastern European regions are becoming an increasingly popular destination for service-based FDI.

20. Some recent papers showing the existence of geographical concentration on FDI are, for example, Yavan (2010) for the Turkish case, and Holl et al. (2012) and Villaverde and Maza (2012) for the Spanish case.

\section{References}

Anselin, L. (1980) Estimation Methods for Spatial Autoregressive Structures, Regional Science Dissertation and Monograph Series (Ithaca, NY: Cornell University).

Basile, R., Castellani, D. \& Zanfei, A. (2008) Location choices of multinational firms in Europe: The role of EU cohesion policy, Journal of International Economics, 74, pp. 328-340. doi:10.1016/j.jinteco.2007.08.006

Basile, R., Castellani, D. \& Zanfei, A. (2009) National boundaries and the location of multinational firms in Europe, Papers in Regional Science, 88(4), pp. 733-748. doi:10.1111/j.1435-5957.2009.00238.x

Blonigen, B. A. (2005) A review of the empirical literature on FDI determinants, Atlantic Economic Journal, 33 , pp. 383-403. doi:10.1007/s11293-005-2868-9

Buckley, P. J. \& Casson, M. C. (1976) The Future of Multinational Enterprise (London: Macmillan).

Capello, R., Fratesi, U. \& Resmini, L. (2011) Globalization and Regional Growth in Europe. Past Trends and Future Scenarios (Berlin: Springer-Verlag).

Casi, L. \& Resmini, L. (2010) Evidence on the determinants of foreign direct investment: The case of EU regions, Eastern Journal of European Studies, 1(2), pp. 93-118.

Castiglione, C., Gorbunova, Y., Infante, D. \& Smirnova, J. (2012) FDI determinants in an idiosyncratic country. A reappraisal over the Russian regions during transition years, Communist and Post-Communist Studies, 45 , pp. 1-10. doi:10.1016/j.postcomstud.2012.02.006

Chidlow, A., Salciuviene, L. \& Young, S. (2009) Regional determinants of inward FDI distribution in Poland, International Business Review, 18(2), pp. 119-133. doi:10.1016/j.ibusrev.2009.02.004

DiStefano, C., Zhu, M. \& Mindrila, D. (2009) Understanding and using factor scores: Considerations for the applied researcher, Practical Assessment, Research and Evaluation, 14(20). Available at http:// pareonline.net/getvn.asp? $\mathrm{v}=14 \& \mathrm{n}=20$ (accessed1 January 2014).

Dunning, J. H. (1977) Trade, location of economic activity and the MNE: A search for an eclectic approach, in: B. Ohlin, P. O. Hesselborn \& P. M. Wijkman (Eds) The International Allocation of Economic Activity, pp. 395-418 (London: Holmes and Meier).

Dunning, J. H. (1979) Explaining changing pattern of international production: In defence of eclectic theory, Oxford Bulletin of Economics and Statistics, 41, pp. 269-295. doi:10.1111/j.1468-0084.1979. mp41004003.x

Dunning, J. H. (1993) Multinational Enterprises and the Global Economy (Harlow: Addison-Wesley).

Dunning, J. H. (2000) The eclectic paradigm as an envelope for economic and business theories of MNE activity, International Business Review, 9, pp. 163-190. doi:10.1016/S0969-5931(99)00035-9

Dunning, J. H. (2002) Global Capitalism, DFI and Competitiveness (Cheltenham: Edward Elgar).

Dunning, J. H. (2009) Location and the multinational enterprise: A neglected factor? Journal of International Business Studies, 40(1), pp. 5-19. doi:10.1057/jibs.2008.74 


\section{A. Maza \& J. Villaverde}

Dunning, J. H. \& Lundan, S. M. (2008) Multinational Enterprises and the Global Economy, 2nd ed. (Cheltenham, MA: Edward Elgar).

Faeth, I. (2009) Determinants of foreign direct investment. A tale of nine theoretical models, Journal of Economic Surveys, 23(1), pp. 165-196. doi:10.1111/j.1467-6419.2008.00560.x

Fallon, G. \& Cook, M. (2010) Exploring the regional distribution of inbound foreign direct investment in the UK in theory and practice: Evidence from a five-region study, Regional Studies, 44(3), pp. 337-353. doi:10. 1080/00343400802378735

Holl, A., Pardo, R. \& Rama, R. (2012) Comparing outsourcing patterns in domestic and FDI manufacturing plants: Empirical evidence from Spain, European Planning Studies, 20(8), pp. 1335-1357. doi:10.1080/ 09654313.2012 .680582

Hymer, S. H. (1960) The international operation of national firms: A study of direct investment, Ph.D. Dissertation, Published by MIT Press in 1976.

Kandogan, Y. (2012) Regional foreign direct investment potential of the states within the US, Journal of Economics and Business, 64, pp. 306-322. doi:10.1016/j.jeconbus.2012.03.004

Kojima, K. (1973) A macroeconomic approach to foreign direct investment, Hitotsubashi Journal of Economics, 14 , pp. $1-20$.

Kojima, K. \& Ozawa, T. (1984) Micro- and macro-economic models of direct foreign investment: Toward a synthesis, Hitotsubashi Journal of Economics, 25(1), pp. 1-20.

Majocchi, A. \& Presutti, M. (2009) Industrial clusters, entrepreneurial culture and the social environment: The effects on FDI distribution, International Business Review, 18, pp. 76-88. doi:10.1016/j.ibusrev.2008.12. 001

Markusen, J. R. \& Venables, A. J. (1999) Foreign direct investment as a catalyst for industrial development, European Economic Review, 43, pp. 335-356. doi:10.1016/S0014-2921(98)00048-8

Maza, A. \& Villaverde, J. (2011) EU regional convergence and policy: Does the concept of region matter? Journal of Policy Modeling, 33, pp. 889-900. doi:10.1016/j.jpolmod.2011.03.007

Nardo, M., Saisana, M., Salteyi, A. \& Tarantola, S. (2005) Handbook on Constructing Composite Indicators: Methodology and User Guide (Paris: OECD, STD/DOC 3).

Phelps, N. A. \& Raines, P. (2003) The New Competition for Inward Investment: Companies, Institutions and Territorial Development (Cheltenham: Edward Elgar).

Polasek, W. \& Sellner, R. (2010) Spatial Chow-Lin Methods for Data Completion in Econometric Flow Models (Vienna: Institute for Advances Studies, Economic Series 255).

Polasek, W. \& Sellner, R. (2011) Does Globalization Affect Regional Growth? Evidence for NUTS-2 Regions in EU27 (Vienna: Institute for Advances Studies, Economic Series 266).

Polasek, W. \& Sellner, R. (2013) Does globalization affect regional growth? Evidence for NUTS-2 regions in EU27, Danube, 4(1), pp. 23-65. doi:10.2478/danb-2013-0002

Rodríguez, C., Gómez, C., \& Ferreiro, J. (2009) A proposal to improve the UNCTAD's inward FDI potential index, Transnational Corporations, 18(3), pp. 85-114.

Sass, M. \& Fifekova, M. (2011) Offshoring and outsourcing business services to central and Eastern Europe: Some empirical and conceptual considerations, European Planning Studies, 19(9), pp. 1593-1609. doi:10.1080/09654313.2011.586196

UNCTAD. (2001) World Investment Report, 2001 (Geneva: United Nations).

UNCTAD. (2002) World Investment Report, 2002 (Geneva: United Nations).

UNCTAD. (2012) World Investment Report, 2012 (Geneva: United Nations).

Vernon, R. (1966) International investment and international trade in the product cycle, The Quarterly Journal of Economics, 80, pp. 190-207. doi:10.2307/1880689

Villaverde, J. \& Maza, A. (2012) Foreign direct investment in Spain: Regional distribution and determinants, International Business Review, 21, pp. 722-733. doi:10.1016/j.ibusrev.2011.08.004

Villaverde, J. \& Maza, A. (2015) The determinants of inward foreign direct investment: Evidence from the European regions, International Business Review, 24, pp. 209-223. doi:10.1016/j.ibusrev.2014.07.008

Voinea, C. L. \& Van Kranenburg, H. (2011) Colocation patterns of foreign-owned firms in a small open economy: Evidence from the Netherlands, European Planning Studies, 19(12), pp. 2047-2072. doi:10.1080/ 09654313.2011 .633823

Yavan, N. (2010) The location choice of foreign direct investment within Turkey: An empirical analysis, European Planning Studies, 18(10), pp. 1675-1705. doi:10.1080/09654313.2010.504350 


\section{Appendix}

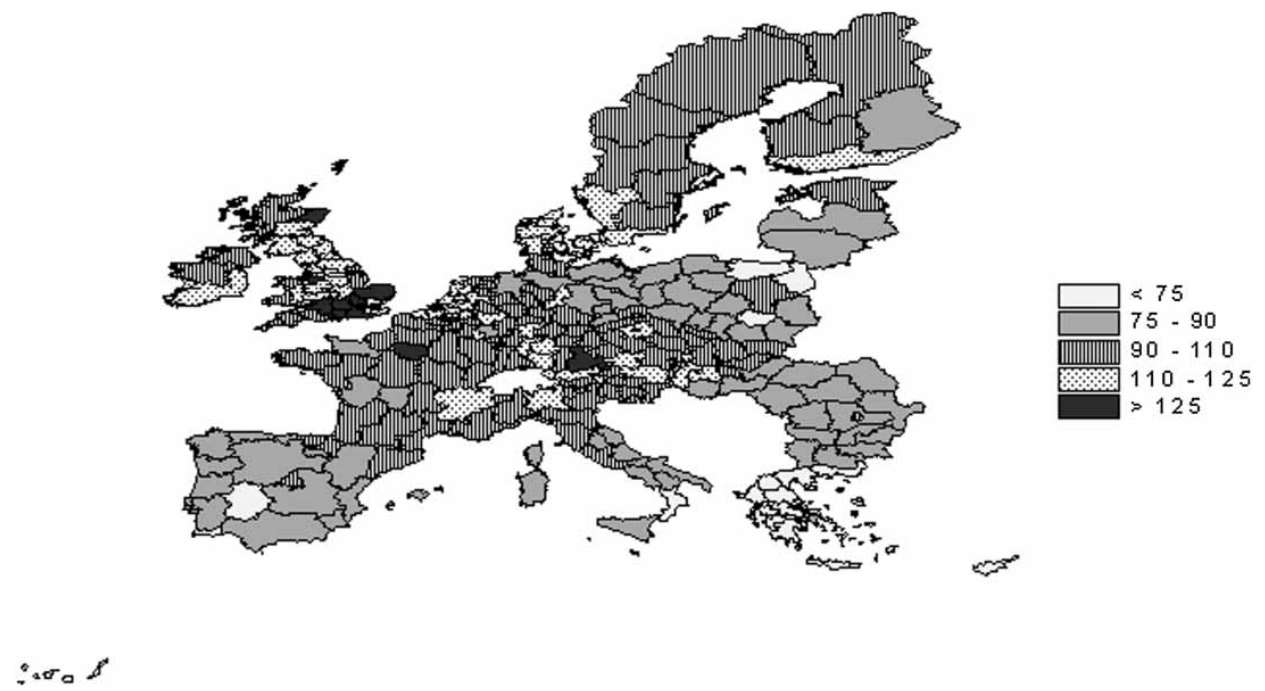

Figure A1. Un-weighted linear average FDI Potential Index $(E U=100)$.

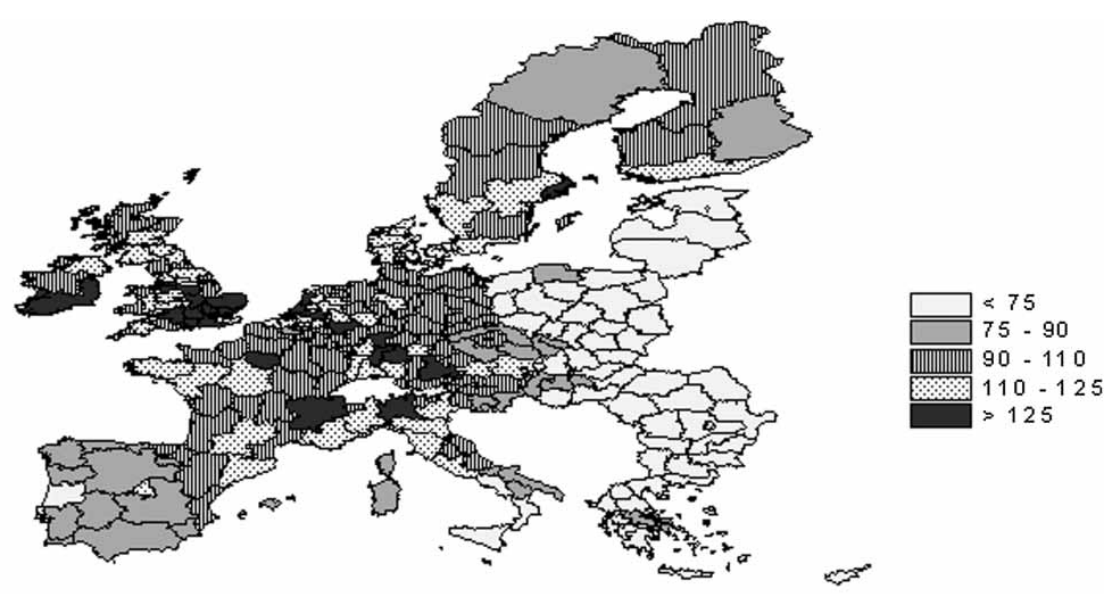

Figure A2. Weighted geometric average FDI Potential Index $(E U=100)$. 